\title{
Late Ordovician (Sandbian) bryozoans and their depositional environment, Furuberget Formation, Mjøsa District, Oslo Region, Norway
}

\author{
ANDREJ ERNST \& HANS ARNE NAKREM
}

\begin{abstract}
A stenolaemate bryozoan fauna from the Late Ordovician (Sandbian) Furuberget Formation of the Mjøsa district, southern Norway contains 10 species. One species belongs to the Order Cyclostomata: Corynotrypa delicatula (James, 1878). Five species belong to the Order Trepostomata: Parvohallopora ramosa (d'Orbigny, 1850), Mesotrypa orientalis Bassler, 1911, Mesotrypa egena Bassler, 1911, Dekayia sugarensis Ross, 1969, and Eridotrypa aedilis (Eichwald, 1855). Four species belong to the Suborder Ptilodictyina of the Order Cryptostomata: Graptodictya perelegans (Ulrich, 1878), Oanduellina leuchtenbergi Pushkin, 1977, Phaenopora similis Nekhoroshev, 1961, and Ptilodictya capillaris Lavrentjeva (in Gorjunova \& Lavrentjeva, 1993). The bryozoan faunal association is similar to that found in time-equivalent Baltoscandian and Laurentian units elsewhere. Their known biostratigraphic range is generally Late Ordovician (Sandbian-Katian). $•$ Key words: Late Ordovician, Bryozoa, Norway, taxonomy, palaeobiogeography.
\end{abstract}

ERnST, A. \& NAKREM, H.A. 2011. Late Ordovician (Sandbian) bryozoans and their depositional environment, Furuberget Formation, Mjøsa District, Oslo Region, Norway. Bulletin of Geosciences 87(1), 21-44 (13 figures, 10 tables). Czech Geological Survey, Prague. ISSN 1214-1119. Manuscript received September 9, 2011; accepted in revised form November 23, 2011; published online December 14, 2011; issued February 29, 2012.

Andrej Ernst, Institut für Geowissenschaften der Christian-Albrechts-Universität zu Kiel, Ludewig-Meyn-Str. 10, D-24118 Kiel, Germany; ae@gpi.uni-kiel.de • Hans Arne Nakrem, Natural History Museum (Geology), University of Oslo, P.O. Box 1172 Blindern, NO-0318Oslo, Norway; h.a.nakrem@nhm.uio.no

The Furuberget Formation is widely distributed in the Mjøsa district in the northern part of the Oslo Region (Fig. 1A). Here the base of the Furuberget Formation is in a gradational sequence from the grey shales of the underlying Hovinsholm Formation to green/grey shales with limestones and calcareous siltstones. The age of the unit, as based on brachiopods and trilobites has recently been refined as Sandbian by Bergström et al. (2011) based on $\delta^{13} \mathrm{C}$ chemostratigraphy of the overlying Mjøsa Formation (Fig. 1B). The fauna of the Furuberget Formation is, in addition to bryozoans, characterized by brachiopods, trilobites and various algae, e.g. Coelosphaeridium (Owen et al. 1990).

\section{Depositional environment}

The bryozoan samples investigated herein are fossiliferous and represent organic rich peloidal floatstone to rudstone with significant siliciclastic components (Fig. 2A). Abundant bryozoans, trilobites, brachiopods, gastropods, echinoderms (pelmatozoans) and calcareous algae (Coelosphaeridium sp.) are common in investigated thin sections.
Skeletal remains of some bryozoans, brachiopods and trilobites are locally silicified (Fig. 2C). Trilobites, probably of the genus Chasmops are represented by large forms, often having large schizochroal eyes (Fig. 2B-D).

The matrix consists of different components, among them the most important are calcite (sparite), quartz and fecal peloids. Sparitic calcite occurs between other components and in former voids (e.g. bryozoan chambers). Quartz grains are irregularly polygonal, $0.02-0.08 \mathrm{~mm}$ in diameter. The peloids are represented by rounded to oval micritic grains, 0.03-0.06 $\mathrm{mm}$ in diameter (Fig. 4B-F). The grains show mainly homogenous internal structure.

Based on the faunal components and sedimentary information the depositional environment of the investigated part of the Furuberget Formation can be interpreted as a slightly deepened basin within the photic zone (algae and trilobites with large eyes), and below the storm wave base. The high portion of siliciclastic components infers a placement of this basin not far away from land or a delta system. Bryozoans, brachiopods and pelmatozoans are suspension feeders which in turn indicates that the environment in which the fauna derives from was nutrition rich, mesotrophic, or even eutrophic. The source of the fecal 


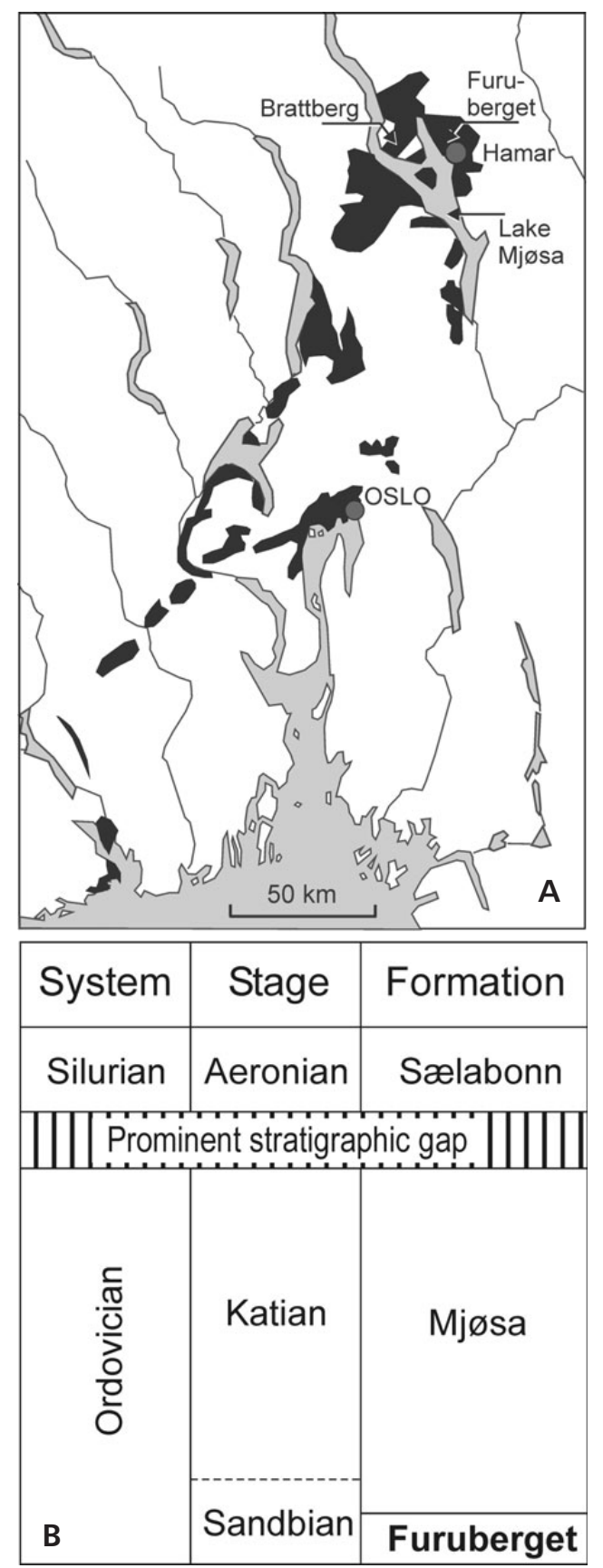

Figure 1. Locality map (A) and stratigraphy (B).

peloids is not fully understood. According to their size, their producers can be brachiopods or pelmatozoans, because they appear to be too large for bryozoans and too small for trilobites. Gastropods are not present in large numbers and it seems unlikely that they could produce such amount of fecal peloids.

\section{Material and methods}

All bryozoan samples come from the Furuberget locality (UTM WGS84 32V 610 6743), except for the Corynotrypa delicatula specimen which is from Brattstad (UTM WGS84 32V 598 6746). The investigated bryozoans were studied from thin sections using a transmitted light binocular microscope. Sixty six oriented and non-oriented thin sections were used. The Corynotrypa delicatula specimen was identified from in imprint in a gastropod steinkern. The material is housed at the Natural History Museum (Geology), Oslo, under numbers PMO 221.294 to 221.370.

Morphological character terminology is adopted from Anstey \& Perry (1970) for trepostomes, Hageman (1993) for cryptostomes and Taylor \& Wilson (1994) for Corynotrypa delicatula. The following morphologic characters were measured for statistical use:

Branch width, branch thickness, exo- (endo-) zone width, autozooecial aperture width, autozooecial aperture spacing (along/across branch), acanthostyle diameter, wall thickness in exozone, and macular diameter (spacing), autozooecial diaphragm spacing, meso- (exila-) zooecia width, meso- (exila-) zooecial diaphragm spacing.

The spacing of structures was measured as the distance between centres. Additional quantitative characters include the number of mesozooecia, exilazooecia and acanthostyles surrounding each autozooecial aperture. Statistics were summarized using arithmetic mean, sample standard deviation, coefficient of variation, and minimum and maximum values.

\section{Systematic palaeontology}

Phylum Bryozoa Ehrenberg, 1831

Class Stenolaemata Borg, 1926

Order Cyclostomata Busk, 1852

Suborder Paleotubuliporina Brood, 1973

Family Corynotrypidae Dzik, 1981

\section{Genus Corynotrypa Bassler, 1911}

Type species. - Hippothoa delicatula James, 1878. Upper Ordovician; North America.

Figure 2. A - floatstone with branched colonies of trepostome bryozoans [Parvohallopora ramosa (d'Orbigny, 1850), Eridotrypa aedilis (Eichwald, 1855)], PMO 221.304.• B - tangential section of schizochroal trilobite eye, PMO 221.362. • C - longitudinal section of the trilobite carapace with schizochroal eye (arrow - partial silicification), PMO 221.340. • D - longitudinal section of calcareous alga Coelosphaeridium sp., PMO 221.348. 

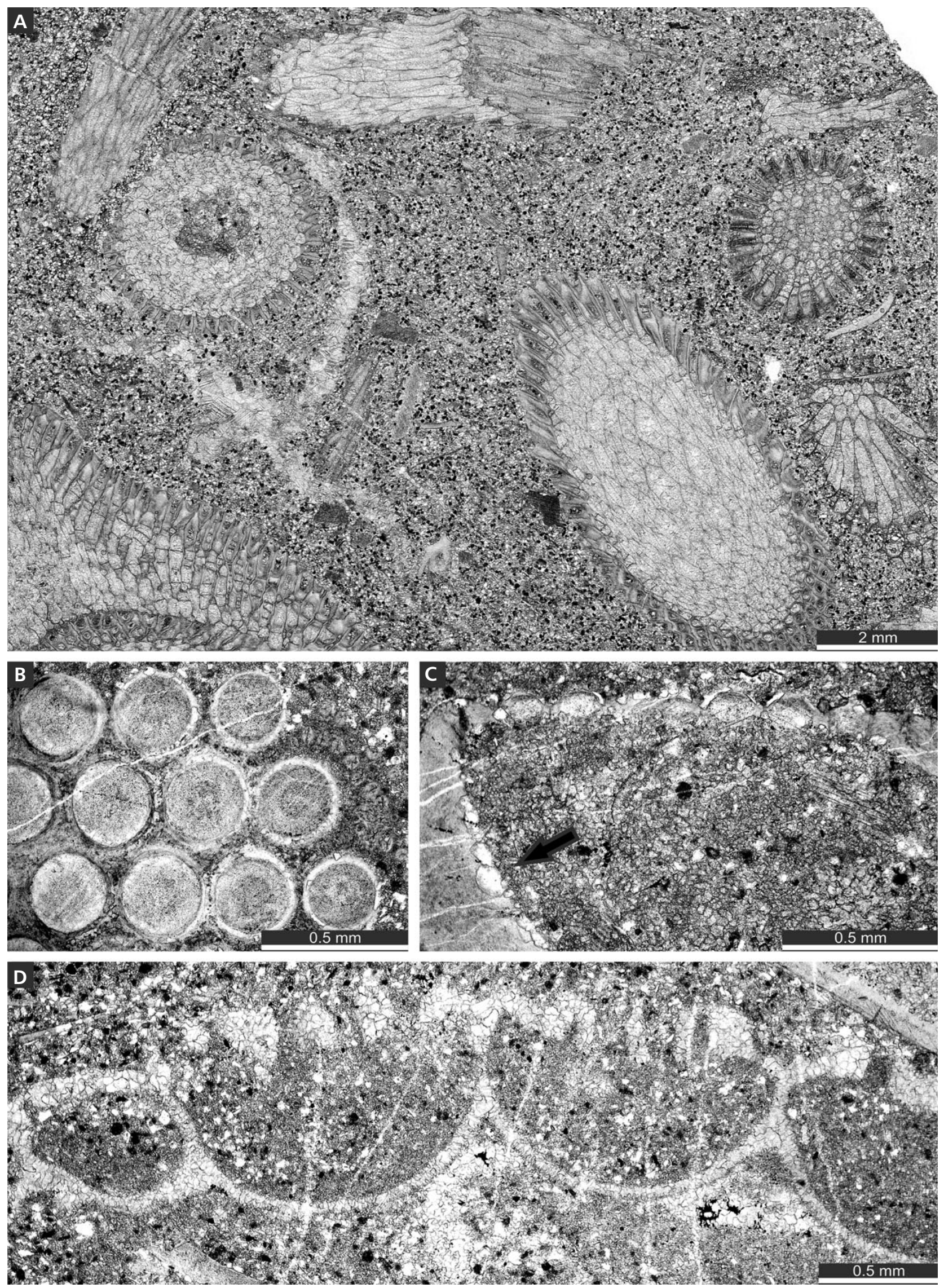

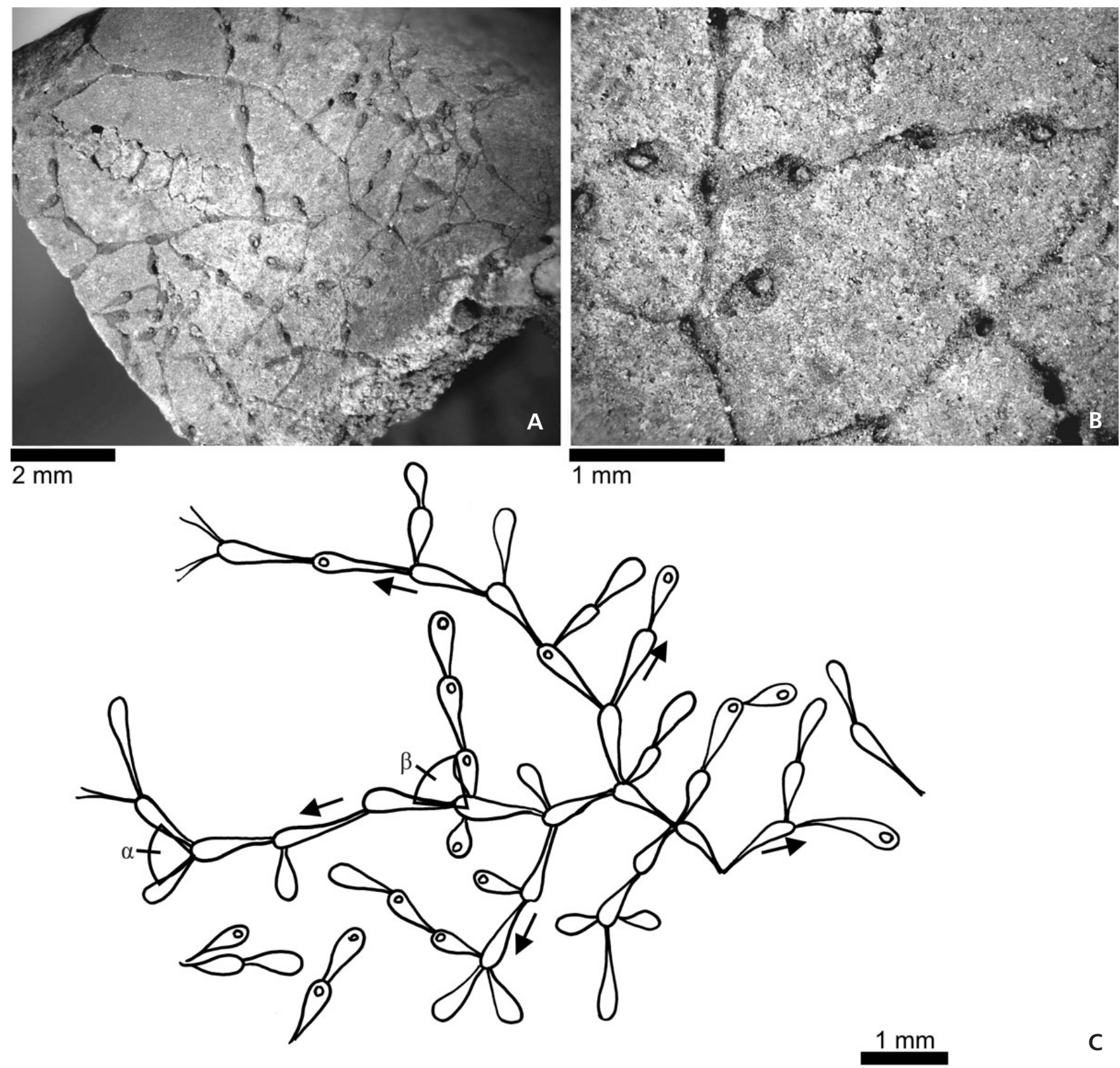

Figure 3. Corynotrypa delicatula (James, 1878), PMO 221.354. • A, B - imprints (natural casts) of Corynotrypa delicatula in a silt steinkern. - $\mathrm{C}$-drawing of part of a Corynotrypa delicatula colony. Arrows indicate colony growth directions. $\alpha-$ bifurcation angle, $\beta$ - lateral ramification angle.

Diagnosis. - See Taylor \& Wilson, 1994.

Occurrence. - Ordovician-Permian; worldwide.

\section{Corynotrypa delicatula (James, 1878)}

Figure 3A-C, Table 1

Material. - PMO 221.354. Single colony preserved as cast in a steinkern of an unknown gastropod.

Description. - Colony encrusting uniserial, runner-like colony. Autozooecia monomorphic but astogenetically variable moderately long and slender, with relatively short and narrow proximal portion. Observed range of length 0.60 to $1.15 \mathrm{~mm}$, width $0.20-0.26 \mathrm{~mm}$. Exterior wall not observed (dissolved). Branches divide at intervals by bifurcation, and by lateral ramifications of little variation in angles, averaging 75 to $78^{\circ}$. Apertures rounded, $0.06-0.10 \mathrm{~mm}$ in diameter. Ancestrula not observed.

Comparison. - Corynotrypa delicatula is distinguished from C. inflata (James, 1878) and other species of Cory- 

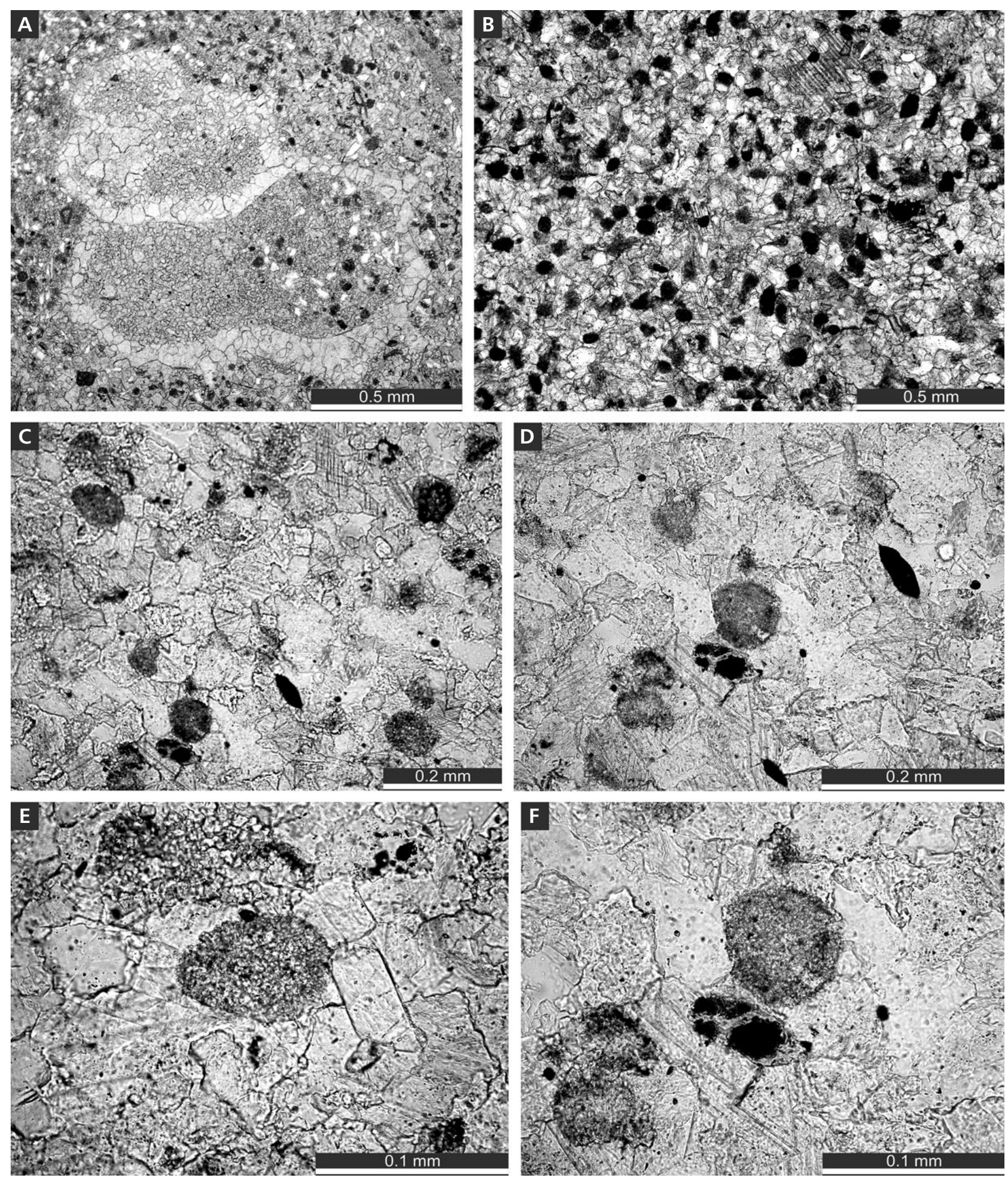

Figure 4. A - gastropod shell, PMO 221.346. • B, C - matrix containing quartz grains, fecal pellets and sparite calcite, PMO 221.304. $\bullet$ D-F - fecal pellets, PMO 221.298.

notrypa by the presence of very long, slender zooids and by the development of secondary zones of astogenetic change (Fig. 5).
Occurrence. - Sandbian-Katian, Upper Ordovician; USA. Sandbian; Estonia. Furuberget Formation, Upper Ordovician (Sandbian); Norway. 


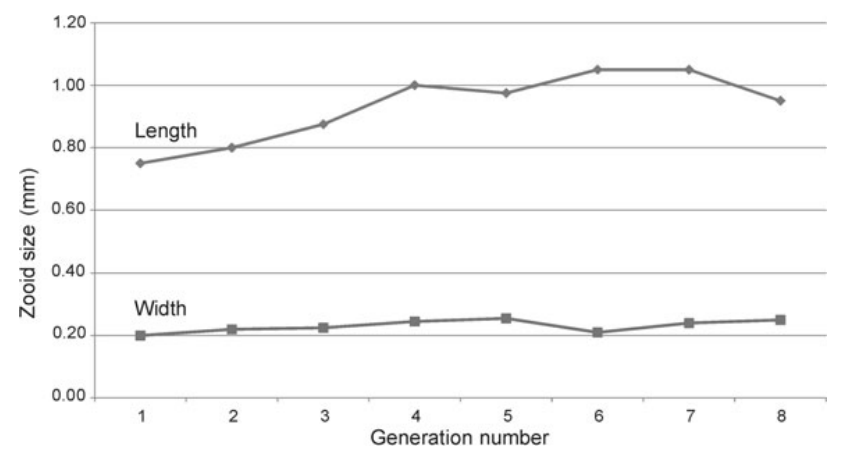

Figure 5. Plot showing changes in zooid length and zooid width along lateral branches of Corynotrypa delicatula. The secondary zone of astogenetic change for zooid length is significantly increasing whereas zooidal width shows little change.

Table 1. Measurements of Corynotrypa delicatula (James, 1878). Abbreviations: N - number of measurements; X - mean; SD - standard deviation; $\mathrm{CV}$ - coefficient of variation; MIN - minimal value; MAX maximal value.

\begin{tabular}{lrrrrrc}
\hline & $\mathrm{N}$ & $\mathrm{X}$ & $\mathrm{SD}$ & $\mathrm{CV}$ & $\mathrm{MIN}$ & $\mathrm{MAX}$ \\
\hline Zooid length, mm & 24 & 0.85 & 0.161 & 18.82 & 0.60 & 1.15 \\
Zooid width, mm & 24 & 0.23 & 0.021 & 9.02 & 0.20 & 0.26 \\
Aperture diameter & 16 & 0.09 & 0.013 & 15.28 & 0.06 & 0.10 \\
Bifurcation angle & 8 & 75.6 & 6.286 & 8.31 & 67.0 & 83.9 \\
Lateral ramification angle & 10 & 77.6 & 10.463 & 13.48 & 57.0 & 88.2 \\
\hline
\end{tabular}

Order Trepostomata Ulrich, 1882

Suborder Halloporina Astrova, 1965

Family Halloporidae Bassler, 1911

\section{Genus Parvohallopora Singh, 1979}

Type species. - Monticulipora ramosa d'Orbigny, 1850. Upper Ordovician; North America.

Diagnosis. - Ramose colonies. Colonial surface smooth or with regularly spaced monticules. Exozone well developed. Autozooecia intersecting colonial surface at sharp angles, polygonal in transverse section in endozone, becoming polygonal or circular to subcircular in exozone. Autozooecial diaphragms planar to curved, rarely cystoidal, usually present in endozone, sometimes absent in exozone. Mesozooecia abundant between most autozooecia, rounded to subrounded or rarely polygonal in transverse section, having diameters less than a half of autozooecia. Mesozooecial diaphragms planar to curved.
Comparison. - Parvohallopora Singh, 1979 differs from Hallopora Bassler, 1911 by its absence of mural spines, smaller and more abundant mesozooecia, polygonal shape of autozooecial transverse section in endozones, rare cystoidal diaphragms, and wall microstructure with $\mathrm{U}$ to $\mathrm{V}$ shaped laminae.

Occurrence. - Middle to Upper Ordovician, North America and Europe.

\section{Parvohallopora ramosa (d'Orbigny, 1850)}

Figures 6A-H, 7A, Table 2

Material. - PMO 221.304, 221.320, 221.330-332, 221.335-336, 221.338-339, 221.341, 221.345-350.

Description. - Ramose colonies, branch diameter 2.9 to $6.2 \mathrm{~mm}$. Exozone $0.38-1.64 \mathrm{~mm}$ wide, endozone 2.14 to $2.92 \mathrm{~mm}$ wide. Autozooecia long, polygonal in transverse section in endozone, growing for a long distance in endozone, then bending gently and intersecting colonial surface at angles of $80-90^{\circ}$. Autozooecial apertures oval to polygonal. Basal diaphragms thin, straight, rare to common in endozones; thick, straight to curved, rarely cystoidal, common to abundant in exozones. Mural spines absent. Mesozooecia abundant, 3-10 surrounding each autozooecial aperture, moderately large to large, polygonal to rounded, originating in the outer endozone, usually closed by skeleton, possessing numerous diaphragms. Mesozooecial diaphragms straight, thin in proximal parts becoming thick near colony surface. Styles absent. Autozooecial walls straight, 0.005 to $0.010 \mathrm{~mm}$ thick in endozone; $0.025-0.100 \mathrm{~mm}$ thick, with distinct reversed $\mathrm{U}$ to $\mathrm{V}$ shaped structure in exozone.

Comparison. - Parvohallopora ramosa (d'Orbigny, 1850) differs from $P$. onealli (James, 1878) in having thicker branches [branch diameter in studied material 2.9-6.2 mm, 3.3-9.2 $\mathrm{mm}$ in type material (Singh 1979, p. 231) vs. 1.2-2.4 mm (Karklins 1984, p. 73) and 2.28-2.80 mm (Ernst \& Key 2007, p. 386) in P. onealli]. Furthermore, autozooecia in Parvohallopora ramosa are oriented at higher angle than those in $P$. onealli $\left(80-90^{\circ}\right.$ vs. $\left.25-35^{\circ}\right)$. Parvohallopora ramosa is also similar to $P$. nodulosa (Nicholson, 1874) from the Upper Ordovician of USA, but differs from it in having abundant diaphragms.

Occurrence. - Upper Ordovician; USA (see Singh 1979,

Figure 6. Parvohallopora ramosa (d'Orbigny, 1850). • A - branch transverse section, short detail, PMO 221.348. • B - branch transverse section, short detail, PMO 221.304. • C - longitudinal section, short detail, PMO 221.329. • D - longitudinal section, short detail, PMO 221.327. • E, F - longitudinal section, short detail, PMO 221.329. • G - branch transverse section showing mesozooecium, PMO 221.348. $\bullet$ H - tangential section, short detail, PMO 221.328. 

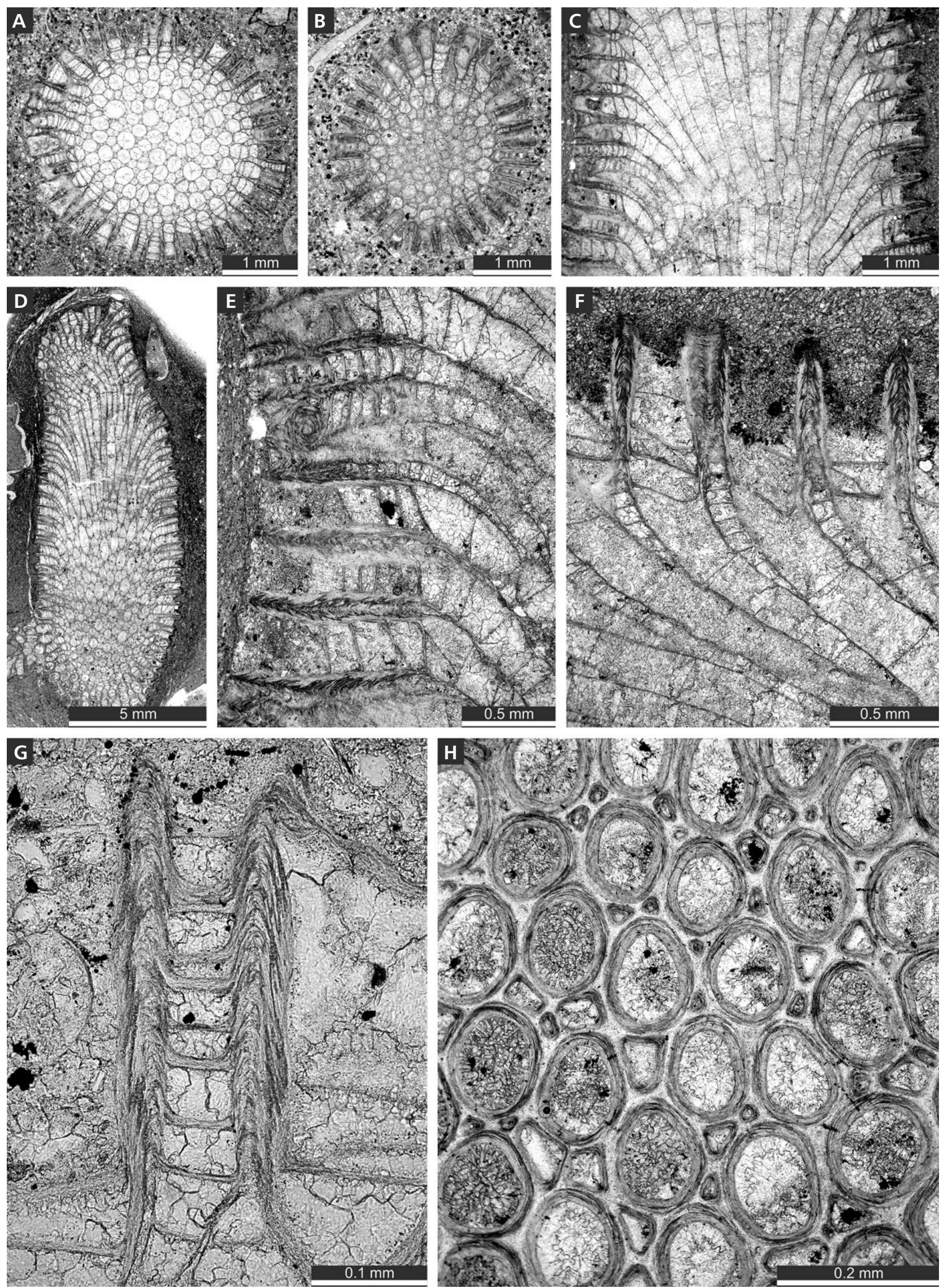
Table 2. Measurements of Parvohallopora ramosa (d'Orbigny, 1850). Abbreviations as in Table 1 .

\begin{tabular}{|c|c|c|c|c|c|c|}
\hline & $\mathrm{N}$ & $\mathrm{X}$ & SD & $\mathrm{CV}$ & MIN & MAX \\
\hline Branch width, mm & 11 & 4.35 & 1.146 & 26.37 & 2.90 & 6.20 \\
\hline Exozone width, mm & 11 & 0.77 & 0.328 & 42.58 & 0.38 & 1.64 \\
\hline Aperture width, mm & 35 & 0.20 & 0.026 & 13.03 & 0.14 & 0.24 \\
\hline Aperture spacing, $\mathrm{mm}$ & 35 & 0.29 & 0.025 & 8.46 & 0.25 & 0.35 \\
\hline Aperture width, mm (macular) & 12 & 0.29 & 0.024 & 8.26 & 0.26 & 0.34 \\
\hline $\begin{array}{l}\text { Aperture spacing, } \mathrm{mm} \\
\text { (macular) }\end{array}$ & 12 & 0.42 & 0.037 & 8.79 & 0.36 & 0.50 \\
\hline Mesozooecia width, mm & 35 & 0.079 & 0.025 & 30.98 & 0.035 & 0.13 \\
\hline Mesozooecia per aperture & 35 & 6.6 & 1.646 & 24.84 & 3.0 & 10.0 \\
\hline $\begin{array}{l}\text { Autozooecial diaphragms } \\
\text { spacing, mm }\end{array}$ & 35 & 0.14 & 0.044 & 31.79 & 0.08 & 0.29 \\
\hline $\begin{array}{l}\text { Mesozooecial diaphragms } \\
\text { spacing, mm }\end{array}$ & 35 & 0.06 & 0.016 & 28.46 & 0.03 & 0.10 \\
\hline Exozonal wall thickness, mm & 35 & 0.055 & 0.020 & 36.76 & 0.025 & 0.10 \\
\hline
\end{tabular}

Table 3. Measurements of Mesotrypa orientalis Bassler, 1911. Abbreviations as in Table 1.

\begin{tabular}{lcccccc}
\hline & $\mathrm{N}$ & $\mathrm{X}$ & $\mathrm{SD}$ & $\mathrm{CV}$ & MIN & MAX \\
\hline Aperture width, mm & 45 & 0.26 & 0.022 & 8.60 & 0.20 & 0.31 \\
Aperture spacing, mm & 45 & 0.29 & 0.030 & 10.34 & 0.25 & 0.39 \\
Mesozooecia width, mm & 45 & 0.071 & 0.021 & 29.29 & 0.025 & 0.130 \\
Mesozooecia per aperture & 45 & 5.2 & 0.894 & 17.20 & 2.0 & 6.0 \\
$\begin{array}{l}\text { Mesozooecial diaphragms } \\
\text { spacing, mm }\end{array}$ & 45 & 0.048 & 0.010 & 21.39 & 0.023 & 0.068 \\
Exozonal wall thickness, mm & 20 & 0.021 & 0.007 & 33.96 & 0.010 & 0.035 \\
\hline
\end{tabular}

pp. 228, 229, for complete synonymy). Furuberget Formation, Upper Ordovician (Sandbian); Norway.

Family Mesotrypidae Astrova, 1965

\section{Genus Mesotrypa Ulrich, 1893}

Type species. - Diplotrypa infida Ulrich, 1886. Middle Ordovician; North America.

Diagnosis. - Massive, hemispheric, conical or discoidal colonies. Autozooecial apertures polygonal or rounded. Walls thin, longitudinally laminated, indistinctly separated. Diaphragms planar, sloped, curved, and funnelshaped. Mesozooecia abundant, budding from base of colony. Acanthostyles may be large, growing from the base of colony, or small, visible at colony surface.

Comparison. - Mesotrypa Ulrich, 1893 differs from the most similar genus Diazipora Vinassa de Regny, 1921 by having acanthostyles and larger mesozooecia.

Occurrence. - Middle Ordovician to Lower Silurian; worldwide.

\section{Mesotrypa orientalis Bassler, 1911}

Figures 7B-I, 8A, B, Table 3

1911 Mesotrypa discoidea orientalis Bassler, pp. 196-198, text-fig. 106.

Material. - PMO 221.315, 221.317, 221.333, 221.334, 221.335, 221.337, 221.339-221.340, 221.341-221.343, 221.345, 221.350, 221.351, 221.353, 221.355-221.358, 221.360-221.362, 221.365, 221.367, 221.369.

Description. - Discoidal colonies with short endozones, 0.8-3.5 mm thick. Secondary overgrowths not observed. Autozooecia bending gently from epitheca, radiating from colony centre to periphery. Autozooecial apertures polygonal. Autozooecial diaphragms abundant, thin, planar or curved, often cystoidal, rare to absent in the outermost parts of autozooecia. Mesozooecia common, 2-6 surrounding each autozooecial aperture, polygonal in transverse section, originating at the base of colony, beaded, bearing straight closely spaced diaphragms. In deeper sections six mesozooecia are arranged in regular hexagonal pattern around autozooecia. Autozooecial walls finely laminated, 0.005 to $0.010 \mathrm{~mm}$ thick in endozone, $0.010-0.035 \mathrm{~mm}$ thick in exozone. Secondary cingulum commonly developed, 0.005-0.010 mm thick, with lamination parallel to autozooecial wall surface. Mural spines common, originating in cingulum, curved proximally. Acanthostyles indistinct, spine-like, positioned in junctions between apertures. Distinct cluster of larger autozooecia in centre of the colony present, $1.05-1.26 \mathrm{~mm}$ in diameter.

Comparison. - Mesotrypa orientalis Bassler, 1911 is similar to M. raritabulata Modzalevskaya, 1953, from the Upper Ordovician (Sandbian) of NW Russia, but differs in having less abundant mesozooecia (2-6 vs. 6-8 in M. raritabulata).

Figure 7. A - Parvohallopora ramosa (d'Orbigny, 1850), tangential section, short detail, PMO 221.328. • B-I - Mesotrypa orientalis Bassler, 1911. - B, C - transverse section of the colony, short detail, PMO 221.345. • D - transverse section of the colony, short detail, PMO 221.356. • E, F - tangential section showing central cluster of zooecia, PMO 221.341. $\bullet \mathrm{G}, \mathrm{H}-$ tangential section showing autozooecial apertures and mesozooecia, PMO 221.315. - I - tangential section showing autozooecial apertures, mesozooecia and acanthostyles, PMO 221.339. 

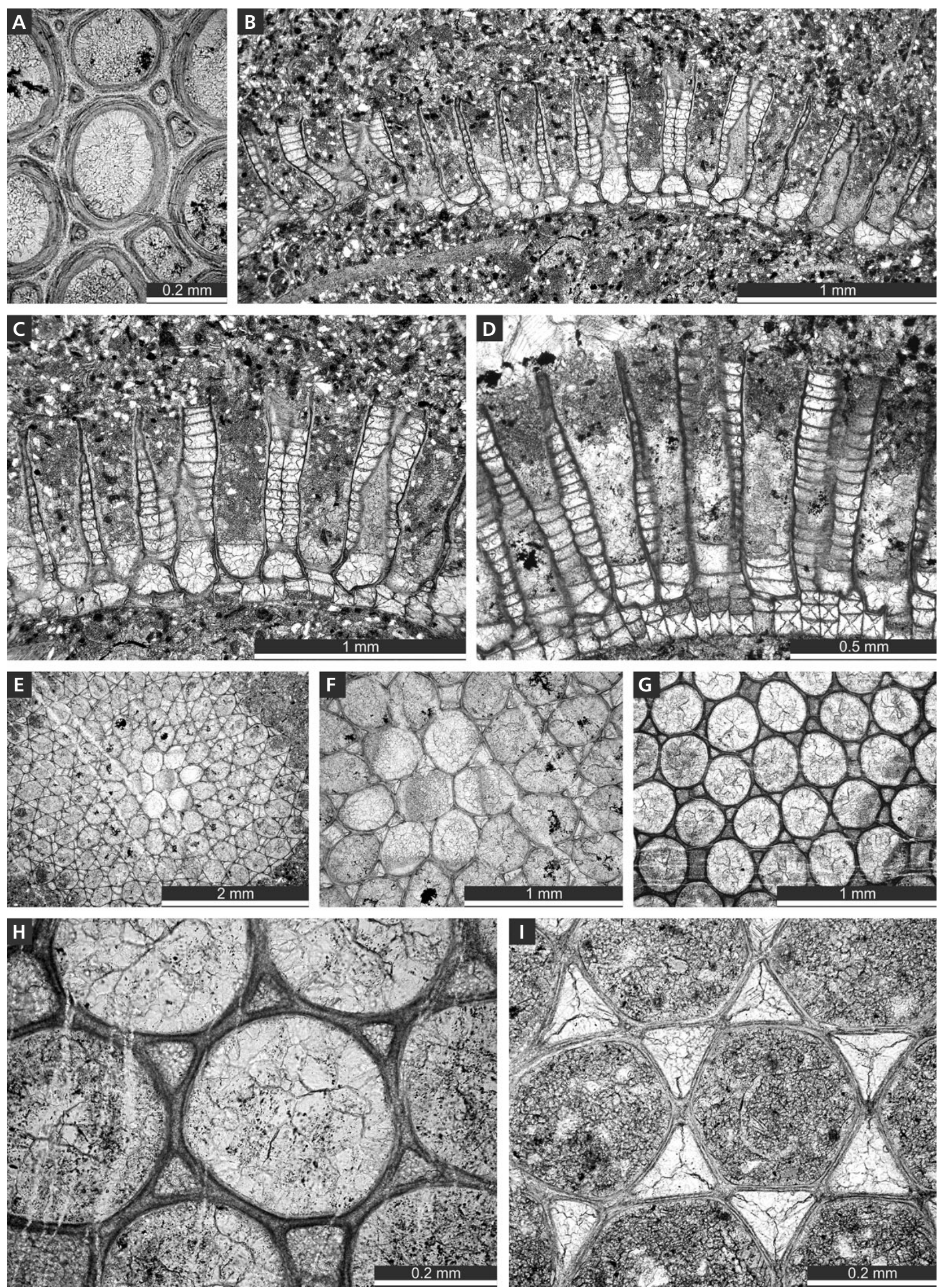
Table 4. Measurements of Mesotrypa egena Bassler, 1911. Abbreviations as in Table 1.

\begin{tabular}{lcccccc}
\hline & $\mathrm{N}$ & $\mathrm{X}$ & $\mathrm{SD}$ & $\mathrm{CV}$ & $\mathrm{MIN}$ & $\mathrm{MAX}$ \\
\hline Aperture width, mm & 40 & 0.30 & 0.022 & 7.17 & 0.25 & 0.36 \\
Aperture spacing, mm & 40 & 0.35 & 0.028 & 7.96 & 0.30 & 0.41 \\
Mesozooecia width, mm & 40 & 0.07 & 0.019 & 26.87 & 0.04 & 0.14 \\
Mesozooecia per aperture & 40 & 4.2 & 1.107 & 26.51 & 2.0 & 6.0 \\
$\begin{array}{l}\text { Mesozooecial diaphragms } \\
\text { spacing, mm }\end{array}$ & 40 & 0.040 & 0.012 & 31.24 & 0.015 & 0.065 \\
$\begin{array}{l}\text { Exozonal wall thickness, mm } \\
\begin{array}{l}\text { Autozooecial diaphragms } \\
\text { spacing, mm }\end{array}\end{array}$ & 40 & 0.03 & 0.007 & 21.95 & 0.02 & 0.05 \\
\hline
\end{tabular}

Occurrence. - Jövi Stage, Upper Ordovician (Sandbian); Estonia. Furuberget Formation, Upper Ordovician (Sandbian); Norway.

\section{Mesotrypa egena Bassler, 1911}

Figure 8C-I, Table 4

1911 Mesotrypa egena Bassler, pp. 198, 199, text-fig. 10.

Material. - PMO 221.314, 221.333, 221.339, 221.340, 221.345, 221.346, 221.348-221.349, 221.352, 221.353, 221.358, 221.366.

Description. - Discoidal colonies with short endozones, 2.8-5.2 mm thick. Secondary overgrowths common, $0.75-1.90 \mathrm{~mm}$ thick. Autozooecia bending gently from epitheca, radiating from colony centre to periphery. Autozooecial apertures polygonal. Autozooecial diaphragms abundant, thin, planar or curved, often cystoidal, rare to absent in the outermost parts of autozooecia. Mesozooecia common, 2-6 surrounding each autozooecial aperture, polygonal in transverse section, originating at the base of colony, beaded, bearing straight closely spaced diaphragms. Autozooecial walls finely laminated, 0.02 to $0.05 \mathrm{~mm}$ thick. Secondary cingulum often developed, 0.005 to $0.015 \mathrm{~mm}$ thick, with lamination parallel to autozooecial wall surface. Mural spines common, originating in cingulum, curved proximally. Acanthostyles indistinct, spine-like, positioned in junctions between apertures. Maculae not observed.

Comparison. - Mesotrypa egena Bassler, 1911 is similar to M. echinata Ulrich \& Bassler, 1904 from the Upper
Ordovician (Trentonian) of USA, but differs in having indistinct acanthostyles instead of large ones in M. echinata. Mesotrypa egena is also similar to M. infida (Ulrich, 1886) from the Upper Ordovician (Trentonian) of USA but differs from it in having indistinct acanthostyles. Mesotrypa egena Bassler, 1911 differs from M. orientalis Bassler, 1911 (present paper) in having larger and wider spaced autozooecial apertures (average aperture width $0.30 \mathrm{~mm}$ vs. $0.26 \mathrm{~mm}$ in $M$. orientalis; average aperture spacing $0.35 \mathrm{~mm}$ vs. $0.29 \mathrm{~mm}$ in $M$. orientalis).

Occurrence. - Keila Stage, Upper Ordovician (Sandbian); Estonia. Furuberget Formation, Upper Ordovician (Sandbian); Norway.

Family Heterotrypidae Ulrich, 1890

\section{Genus Dekayia Milne-Edwards \& Haime, 1851}

Type species. - Dekayia aspera Milne-Edwards \& Haime, 1851. Upper Ordovician (Cincinnatian); North America.

Diagnosis. - Ramose, encrusting or massive colonies. Maculae generally low or flush with the colonial surface and can have megazooecia, slightly larger acanthostyles, and a central cluster of mesozooecia, which is subsolid in some species. Autozooecia are generally angular or subangular in transverse section. Autozooecial walls are characteristically undulatory to crenulated. In exozones individual zooecial walls irregular and thick. Diaphragms commonly absent in inner endozone and either distantly and irregularly spaced or lacking in the outer endozone and the exozone. Mesozooecia rare in intermonticular areas and commonly absent. They consist of series of beaded chambers, visible in some longitudinal and transverse sections. Tubular diaphragms do occur in mesozooecia but are extremely rare. Acanthostyles occur in all species, can originate throughout endozone and inner exozone and some terminate below colony surface.

Comparison. - Dekayia Milne-Edwards \& Haime, 1851 differs from Heterotrypa Nicholson, 1879 by having fewer mesozooecia and usually larger acanthostyles.

Occurrence. - Middle to Upper Ordovician; North America, Europe, India, China.

Figure 8. A, B - Mesotrypa orientalis Bassler, 1911, tangential section showing autozooecial apertures, mesozooecia and mural spines (arrows), PMO 221.333. • C-I - Mesotrypa egena Bassler, 1911. • C - longitudinal section, short detail PMO 221.346; D - longitudinal section, short detail, PMO 221.315. • E-G - longitudinal section showing autozooecial chambers with diaphragms, cingulum and mural spines, PMO 221.346. $\bullet$ H-I - tangential section showing autozooecial apertures and mesozooecia, PMO 221.358. 

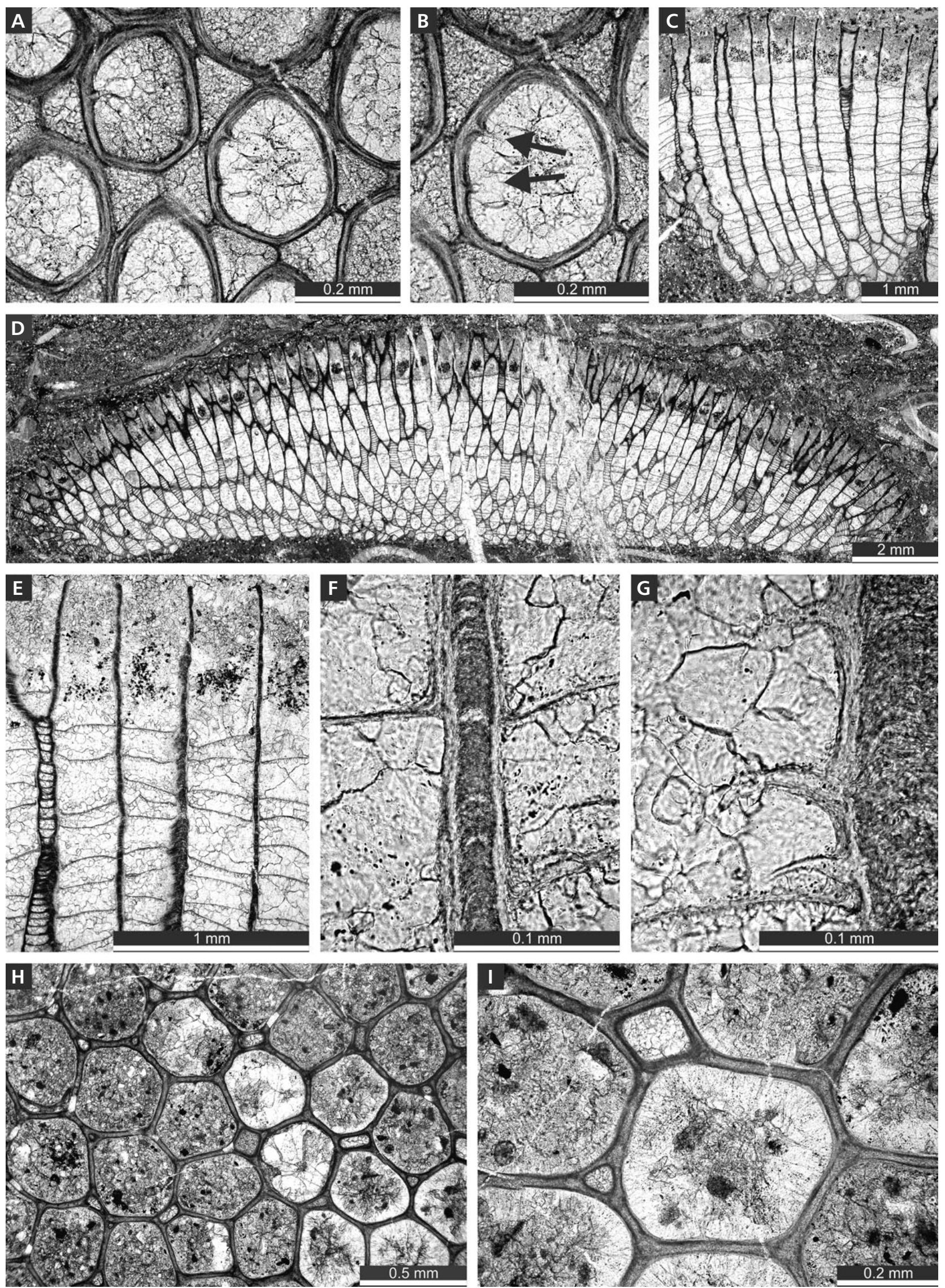
Table 5. Measurements of Dekayia sugarensis Ross, 1969. Abbreviations as in Table 1.

\begin{tabular}{lcccccc}
\hline & $\mathrm{N}$ & $\mathrm{X}$ & $\mathrm{SD}$ & $\mathrm{CV}$ & $\mathrm{MIN}$ & $\mathrm{MAX}$ \\
\hline Aperture width, mm & 25 & 0.21 & 0.025 & 11.92 & 0.17 & 0.26 \\
Aperture spacing, mm & 25 & 0.24 & 0.031 & 12.74 & 0.18 & 0.30 \\
$\begin{array}{l}\text { Aperture width, mm (macular) } \\
\text { Aperture spacing, mm }\end{array}$ & 6 & 0.29 & 0.017 & 5.97 & 0.26 & 0.31 \\
(macular) & 6 & 0.32 & 0.027 & 8.44 & 0.29 & 0.36 \\
Mesozooecia width, mm & 25 & 0.068 & 0.022 & 32.44 & 0.040 & 0.115 \\
Acanthostyle diameter, mm & 25 & 0.053 & 0.011 & 20.38 & 0.035 & 0.075 \\
Acanthostyles per aperture & 25 & 3 & 0.889 & 29.24 & 2 & 5 \\
\hline
\end{tabular}

Dekayia sugarensis Ross, 1969

Figure 9A-F, Table 5

1969 Dekayia sugarensis Ross, pp. 267-270, pl. 39, figs 2, 4-9, pl. 40, figs $1-8$, pl. 41, figs $1-11$, pl. 42, figs $1-9$, table 6.

Material. - PMO 221.295, 221.296, 221.304-221.308, 221.310, 221.370.

Description. - Massive or subramose colonies with indistinct endozones, thickness of massive colonies 0.4 to $1.8 \mathrm{~mm}$, diameter of subramose colonies $4.7-4.8 \mathrm{~mm}$. Autozooecia bending gently from endozone, intersecting colony surface at right angles. Autozooecial apertures rounded to polygonal, often petaloid. Diaphragms in autozooecia rare to common, usually $1-5$ in each autozooecium, thin, straight or slightly curved distally. Mesozooecia rare to common, more abundant in maculae, polygonal in transverse section, bearing thin, common diaphragms, strongly beaded, budding deeply in endozone. Acanthostyles abundant, large, varying in size, prominent, possessing wide hyaline core, 2-5 surrounding each autozooecial aperture. Autozooecial walls granular-prismatic, $0.005-0.010 \mathrm{~mm}$ thick in endozone; irregularly thickened, finely laminated, displaying reverse $\mathrm{V}$-structure in longitudinal section, $0.015-0.025 \mathrm{~mm}$ thick in exozone. Maculae of megazooecia and mesozooecia indistinctly outlined.

Comparison. - Dekayia sugarensis Ross, 1969 differs from D. minima Conti, 1990 from the Upper Ordovician of Sardinia and southern France in having more abundant diaphragms and less abundant acanthostyles (2-5 vs. 2-7 per aperture in D. minima). Dekayia sugarensis differs also from similar D. stidhami (Ulrich, 1890) from the Upper Ordovician of USA in having more abundant diaphragms and mesozooecia.

Occurrence. - Middle-Upper Ordovician (Trentonian); New York, USA. Furuberget Formation, Upper Ordovician (Sandbian); Norway.

Family Trematoporidae Miller, 1889

\section{Genus Eridotrypa Ulrich, 1893}

Type species. - Eridotrypa mutabilis Ulrich, 1893, by original designation. Upper Ordovician; USA.

Diagnosis. - Ramose colonies, with narrow exozone. Autozooecia weakly bending towards branch surface, with oval and oval-rounded apertures, arranged in diagonal rows. Autozooecial walls in exozone thickened, having obliquely laminated microstructure. Diaphragms common throughout colony. Mesozooecia rare, short, differently closed at colony surface. Acanthostyles rare, small and short, sometimes absent. Small, needle-like structures in zooecial walls may occur.

Comparison. - Eridotrypa Ulrich, 1893 differs from the most similar genus Batostoma Ulrich, 1882 by its constant ramose colony form, weak bending of autozooecia to colony surface, short mesozooecia and small, rare acanthostyles and from Bythopora Miller \& Dyer, 1878 by the constant presence of diaphragms in autozooecia and mesozooecia and in its wall microstructure.

Occurrence. - Lower Ordovician to Middle Devonian; Europe, North America, Siberia.

\section{Eridotrypa aedilis (Eichwald, 1855)}

Figures 9G-I, 10A-F, Table 6

1855 Cladopora aedilis Eichwald, p. 457.

1860 Cladopora aedilis Eichwald, 1855. - Eichwald, p. 404 , pl. 24, figs $12,13$.

1877 Monticulipora aedilis (Eichwald, 1855). - Dybowski, p. 98, pl. 3, figs 5, 5a.

1911 Eridotrypa aedilis (Eichwald, 1855). - Bassler, pp. 242-244, pl. 4, figs 5, 5a, text-fig. 137, non fig. 138.

Figure 9. A-F - Dekayia sugarensis Ross, 1969. • A-C - longitudinal section showing autozooecia, mesozooecia and acanthostyles, PMO 221.295. - D-F - tangential section showing autozooecial apertures, acanthostyles and mesozooecia, PMO 221.304. • G-I - Eridotrypa aedilis (Eichwald, 1855). G - branch transverse section, short detail, PMO 221.308; H-I - branch transverse section, short detail, PMO 221.304. 

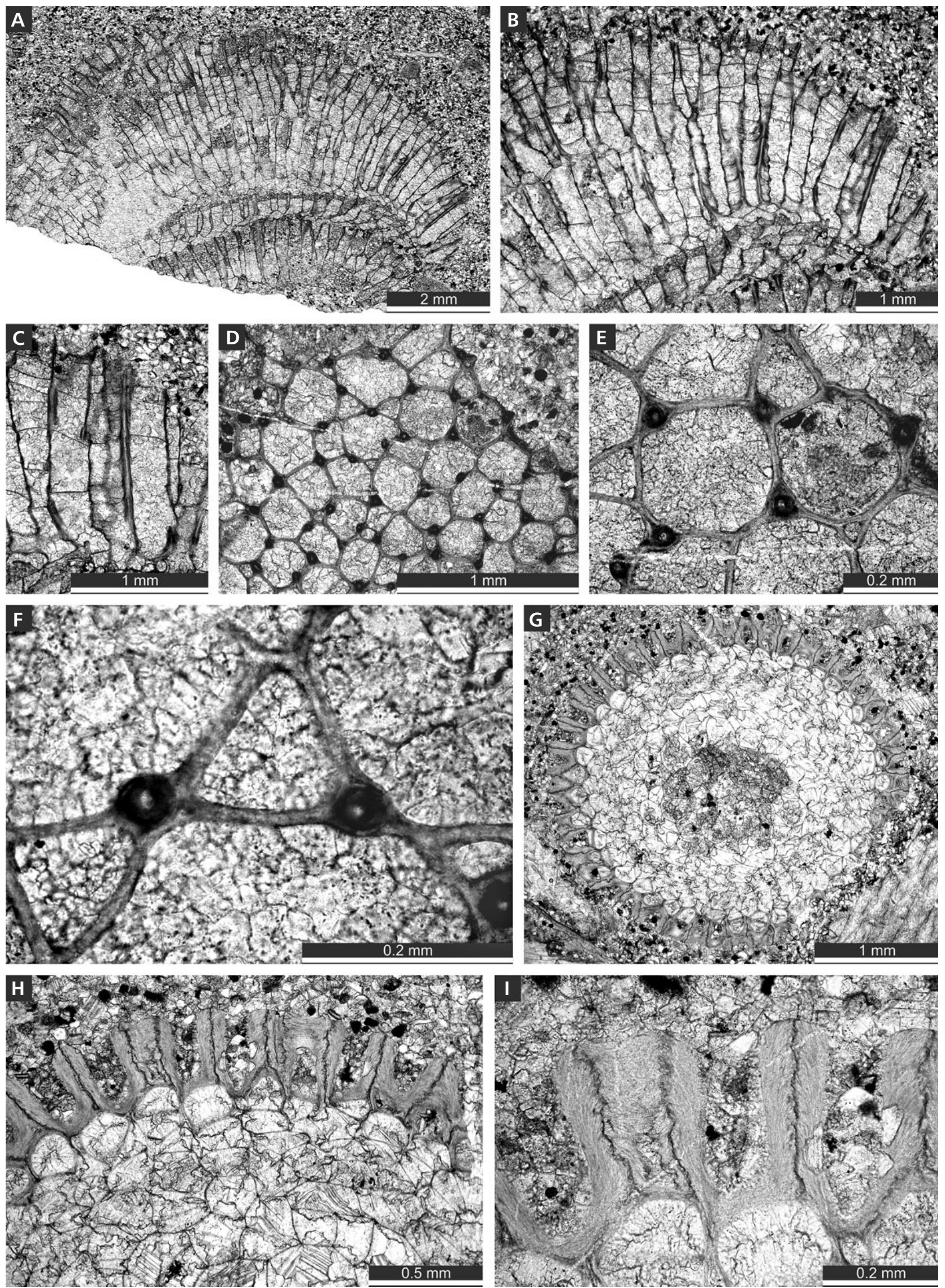
Table 6. Measurements of Eridotrypa aedilis (Eichwald, 1855). Abbreviations as in Table 1.

\begin{tabular}{lcccccc}
\hline & $\mathrm{N}$ & $\mathrm{X}$ & $\mathrm{SD}$ & $\mathrm{CV}$ & $\mathrm{MIN}$ & $\mathrm{MAX}$ \\
\hline Branch width, mm & 15 & 3.82 & 0.579 & 15.17 & 3.10 & 5.10 \\
Exozone width, mm & 15 & 0.66 & 0.206 & 31.26 & 0.30 & 1.08 \\
Endozone width, mm & 15 & 2.50 & 0.557 & 22.26 & 1.74 & 3.84 \\
Aperture width, mm & 30 & 0.09 & 0.015 & 16.91 & 0.07 & 0.13 \\
Aperture spacing, mm & 30 & 0.24 & 0.033 & 14.01 & 0.18 & 0.30 \\
Aperture width, mm (macular) & 10 & 0.19 & 0.017 & 9.21 & 0.16 & 0.22 \\
Aperture spacing, mm (macular) & 10 & 0.31 & 0.035 & 11.17 & 0.26 & 0.36 \\
Mesozooecia width, mm & 20 & 0.05 & 0.013 & 28.58 & 0.03 & 0.08 \\
Acanthostyle diameter, mm & 20 & 0.03 & 0.008 & 22.68 & 0.02 & 0.05 \\
$\begin{array}{l}\text { Mesozooecial diaphragms } \\
\text { spacing, mm }\end{array}$ & 30 & 0.08 & 0.020 & 25.71 & 0.04 & 0.11 \\
$\begin{array}{l}\text { Autozooecial diaphragms } \\
\text { spacing, mm }\end{array}$ & 30 & 0.15 & 0.052 & 35.51 & 0.08 & 0.28 \\
Exozonal wall thickness, mm & 30 & 0.12 & 0.030 & 25.42 & 0.06 & 0.20 \\
Axial zooecia width, mm & 25 & 0.33 & 0.049 & 14.88 & 0.25 & 0.43 \\
\hline
\end{tabular}

1984 Eridotrypa aedilis (Eichwald, 1855) - Karklins, pl. 25, figs 1,2 .

Material. - PMO 221.296, 221.297, 221.301, 221.302 to 221.305, 221.310-221.312, 221.361-221.362, 221.370.

Description. - Ramose colonies, branch diameter 3.10 to $5.10 \mathrm{~mm}$, with $0.30-1.08 \mathrm{~mm}$ wide exozones and 1.74 to $3.84 \mathrm{~mm}$ wide endozones. Autozooecia long, oriented for long distance parallel to branch axis, then bending at angles of $24-30^{\circ}$ in exozone and intersecting colonial surface at angles of $45-70^{\circ}$, polygonal and having larger diameter in endozone, oval to rounded-polygonal in exozone. Autozooecial diaphragms spaced widely in endozone, more densely in inner exozone, and usually absent in outermost parts of zooecia. Mesozooecia rare, small, short, polygonal in transverse section, spaced usually at junctions between autozooecia, bearing closely spaced diaphragms. Acanthostyles rare to common, small, having indistinct cores, restricted to the outermost exozone. Autozooecial walls in endozone having indistinct lamination, 0.005-0.010 mm thick, becoming continually thicker in the inner exozone and up to $0.06-0.20 \mathrm{~mm}$ in the outer exozone. Autozooecial walls in exozone displaying serrated dark border between autozooecia and distinct reverse V-shaped lamination.
Comparison. - Eridotrypa aedilis (Eichwald, 1855) is similar to E. mutabilis Ulrich, 1893 from the Upper Ordovician of USA, but differs from it in having narrower branches (3.1-5.1 mm vs. 2.4-10.8 $\mathrm{mm}$ in E. mutabilis), and in smaller apertures (0.07-0.13 mm vs. $0.16-0.22 \mathrm{~mm}$ in E. mutabilis). Eridotrypa aedilis differs from E. trentonensis (Nicholson, 1881) from the Upper Ordovician of USA in having smaller apertures $(0.07-0.13 \mathrm{~mm}$ vs. $0.10-0.16 \mathrm{~mm}$ in E. trentonensis).

Occurrence. - Jövi, Keila, Oandu and Rakvere Stages, Upper Ordovician (Sandbian-Katian); Estonia. Furuberget Formation, Upper Ordovician (Sandbian); Norway.

Order Cryptostomata Vine, 1884

Suborder Ptilodictyina Astrova \& Morozova, 1956

Family Escharoporidae Karklins, 1983

\section{Genus Graptodictya Ulrich, 1882 [= Arthropora Ulrich, 1882]}

Type species. - Ptilodictya perelegans Ulrich, 1878. Waynesville Shale (Upper Ordovician); Ohio, USA.

Diagnosis. - Branching colonies, irregularly anastomosing in some species. Mesotheca slightly sinuous in longitudinal section, may zigzag in transverse section. Autozooecia budding in exozone at angles $80-90^{\circ}$ to mesotheca. Pustules abundant along autozooecial boundaries and throughout exozonal walls and extrazooecial skeleton. Living chambers elliptical to oval in transverse section. Superior hemisepta common, generally short and blunt, rarely thin and long, curving proximally. Exilazooecia absent to rare, generally subelliptical in transverse section, commonly closed by thickened walls. Monticules absent to rare. Extrazooecial stereom laminae commonly crinkled, forming abundant and longitudinally striae between autozooecia, and along colonial margins and proximal parts of colonies.

Comparison. - Graptodictya Ulrich, 1882 differs from Proavella Männil, 1958 in having branched rather than reticular colonies.

Occurrence. - Middle Ordovician to lower Silurian of Estonia, Sweden, North America.

Figure 10. A-F-Eridotrypa aedilis (Eichwald, 1855). $\bullet$ A - branch longitudinal section, PMO 221.312. • B - longitudinal section of exozone showing autozooecial chambers with diaphragms, PMO 221.294. • C - longitudinal section of exozone showing autozooecial walls, diaphragms and mesozooecium, PMO 221.370. • D - tangential section showing autozooecial apertures, mesozooecia and acanthostyles, PMO 221.294. • E - tangential section showing autozooecial apertures, mesozooecia and acanthostyles, PMO 221.294. • F-branch transverse section of endozone showing central cluster of axial zooecia, PMO 221.370. • G-I - Graptodictya perelegans (Ulrich, 1878). G, H - tangential section, short detail, PMO 221.337; I - tangential section, short detail, PMO 221.334. 

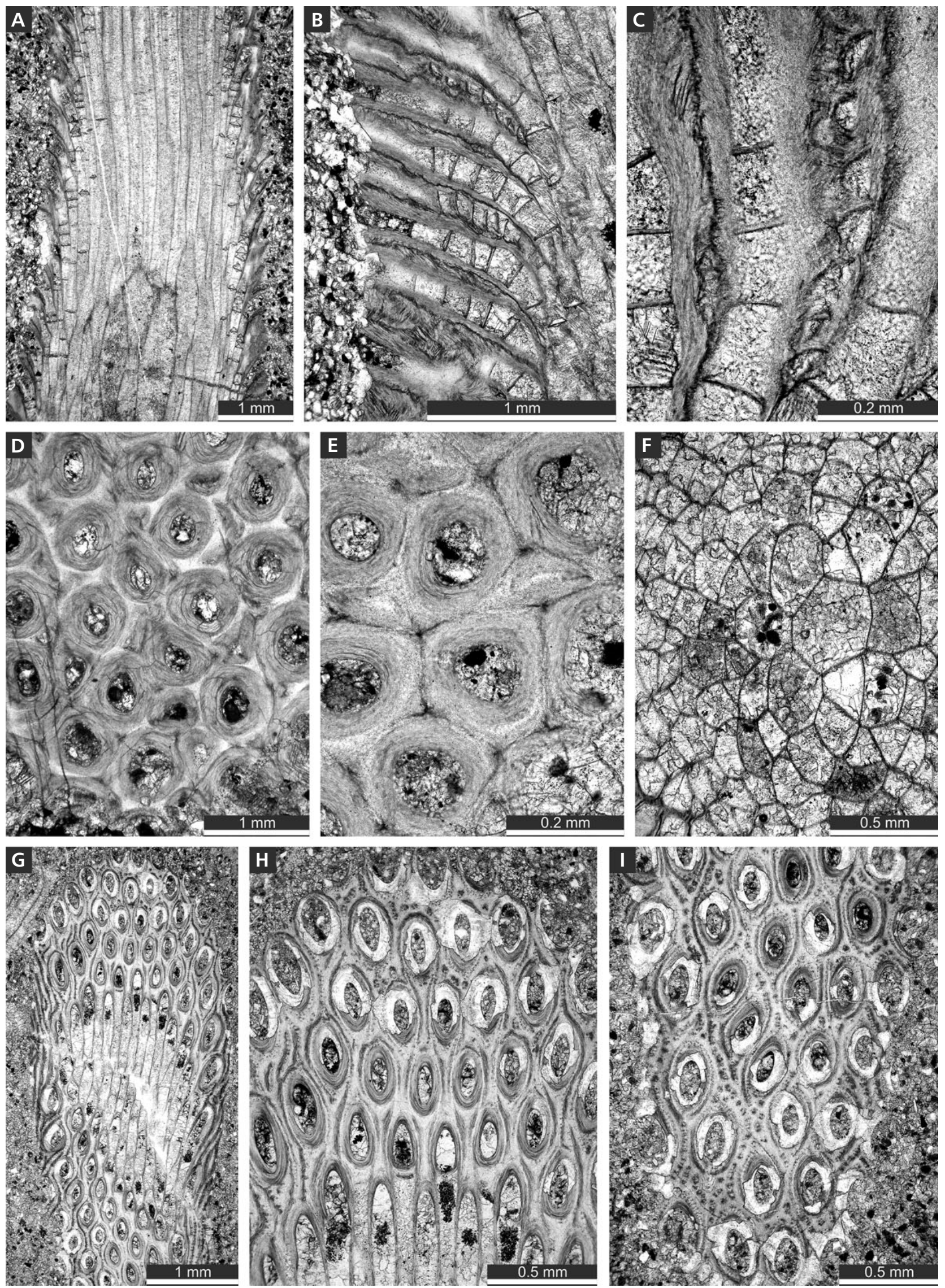
Table 7. Measurements of Graptodictya perelegans (Ulrich, 1878). Abbreviations as in Table 1.

\begin{tabular}{|c|c|c|c|c|c|c|}
\hline & $\mathrm{N}$ & $\mathrm{X}$ & SD & $\mathrm{CV}$ & MIN & MAX \\
\hline Branch width, mm & 8 & 2.18 & 0.322 & 14.75 & 1.63 & 2.58 \\
\hline Branch thickness, mm & 8 & 0.81 & 0.152 & 18.92 & 0.60 & 0.96 \\
\hline Aperture width, mm & 55 & 0.08 & 0.015 & 18.69 & 0.06 & 0.11 \\
\hline $\begin{array}{l}\text { Aperture spacing along branch, } \\
\mathrm{mm}\end{array}$ & 55 & 0.55 & 0.055 & 9.91 & 0.39 & 0.72 \\
\hline $\begin{array}{l}\text { Aperture spacing diagonally, } \\
\mathrm{mm}\end{array}$ & 55 & 0.22 & 0.034 & 15.26 & 0.18 & 0.30 \\
\hline $\begin{array}{l}\text { Autozooecial budding angle, } \\
\text { endozone }\end{array}$ & 7 & 29.6 & 4.276 & 14.46 & 23.0 & 35.0 \\
\hline $\begin{array}{l}\text { Autozooecial budding angle, } \\
\text { exozone }\end{array}$ & 7 & 65.6 & 3.359 & 5.12 & 61.0 & 70.0 \\
\hline
\end{tabular}

Graptodictya perelegans (Ulrich, 1878)

Figures 10G-I, 11A-F, Table 7

1878 Ptilodictya perelegans Ulrich, p. 94, pl. 4, figs 16, 16a.

1882 Graptodictya perelegans (Ulrich, 1878). - Ulrich, p. 165 , pl. 7 , figs $8,8 \mathrm{a}$.

1900 Graptodictya perelegans (Ulrich, 1878). - Nickles \& Bassler, p. 280.

1908 Graptodictya perelegans (Ulrich, 1878). - Cumings, p. 836 , pl. 29 , fig. 8 .

1911 Graptodictya perelegans (Ulrich, 1878). - Bassler, p. 121 , figs $47 \mathrm{a}-\mathrm{d}$.

1953 Graptodictya perelegans (Ulrich, 1878). - Bassler, p. G137, fig. 98, 3a-c.

1960 Graptodictya perelegans (Ulrich, 1878). - Phillips, pp. 19-21, pl. 7, figs 1-3, 6-7, pl. 8, fig. 4.

1983 Graptodictya perelegans (Ulrich, 1878). - Karklins, p. 499 , fig. 247, 1a-f.

1984 Graptodictya perelegans (Ulrich, 1878). - Spjeldnaes, p. 30, pl. 4, figs 9-10, fig. 6E-G.

1993 Graptodictya perelegans (Ulrich, 1878). - Gorjunova \& Lavrentjeva, p. 75, pl. 13, fig. 4.

Material. - PMO 221.316, 221.317, 221.322, 221.329 to 221.330, 221.334, 221.337, 221.338-221.340, 221.353, 221.365 .

Description. - Branching colonies, 1.63-2.58 mm wide, 0.60-0.96 mm thick. Autozooecia quite long, budding in endozone at angles of $23-35^{\circ}$ to the mesotheca, bending in exozone and intersecting branch surface at angles of $61-90^{\circ}$, oval to sub-polygonal in transverse section. Superior hemisepta short and blunt, curving proximally; inferior hemisepta absent. Autozooecial diaphragms occasionally present. Autozooecial apertures oval, arranged in 8-16 regular alternating rows. Heterozooecia absent. Mesotheca straight, 0.005-0.007 mm thick. Extrazooecial skeletal laminae commonly crinkled, forming abundant longitudinal striae between autozooecia, and along branch margins and proximal parts of colonies. Pustules common, 0.010 to $0.025 \mathrm{~mm}$ in diameter, arranged in loose rows between apertures. Small tubules in laminated skeleton occurring.

Comparison. - Graptodictya perelegans (Ulrich, 1878) is similar to G. bonnemai Bassler, 1911 from the Middle Ordovician of Estonia, but differs from it in presence of pustules and larger distances between autozooecial apertures along branch [0.39-0.72 $\mathrm{mm}$ vs. $0.31-0.38 \mathrm{~mm}$ in G. bonnemai (measured on own material from the Kukersite shale of Estonia)]. Graptodictya perelegans is also similar to G. elegantula (Hall, 1847) from the Middle Ordovician of USA, but differs from it in having smaller apertures (0.06-0.11 mm vs. $0.08-0.13 \mathrm{~mm}$ in G. elegantula).

Occurrence. - Upper Ordovician (Richmondian); USA. Upper Ordovician; Ojl Myr, Gotland, Sweden. Furuberget Formation, Upper Ordovician (Sandbian); Norway.

\section{Genus Oanduellina Pushkin, 1977}

Type species. - Oanduellina leuchtenbergi Pushkin, 1977. Nabala Stage, Upper Ordovician (Katian); Latvia.

Diagnosis. - Colonies consisting of dichotomous branches, frond-shaped or anastomosed. Mesotheca straight or slightly undulating, without median rods. Autozooecia short, with flattened proximal parts, rectangular with rounded roofs in transverse section, rectangular at their bases, having oval apertures. Autozooecial diaphragms rare to absent. Superior hemisepta weakly developed, commonly absent; inferior hemisepta absent. Abundant polygonal vesicles occurring in the transition between endozone and exozone, usually covered by extrazooidal material. Extrazooidal material containing paurostyles. Autozooecial walls coarsely laminated. Maculae lacking autozooecia in some species present.

Comparison. - Oanduellina Pushkin, 1977 differs from Sibiredictya Nekhoroshev, 1961 in presence of superior

Figure 11. A-F - Graptodictya perelegans (Ulrich, 1878). • A - tangential section showing autozooecial apertures and pustules, PMO 221.334. - B - branch transverse section, short detail, PMO 221.342. $\bullet$ C, D - branch transverse section, short detail, PMO 221.340. E, F - branch longitudinal section showing autozooecial chambers and hemisepta, PMO 221.353. • G, H - Oanduellina leuchtenbergi Pushkin, 1977, tangential sections, short detail, PMO 221.355. 

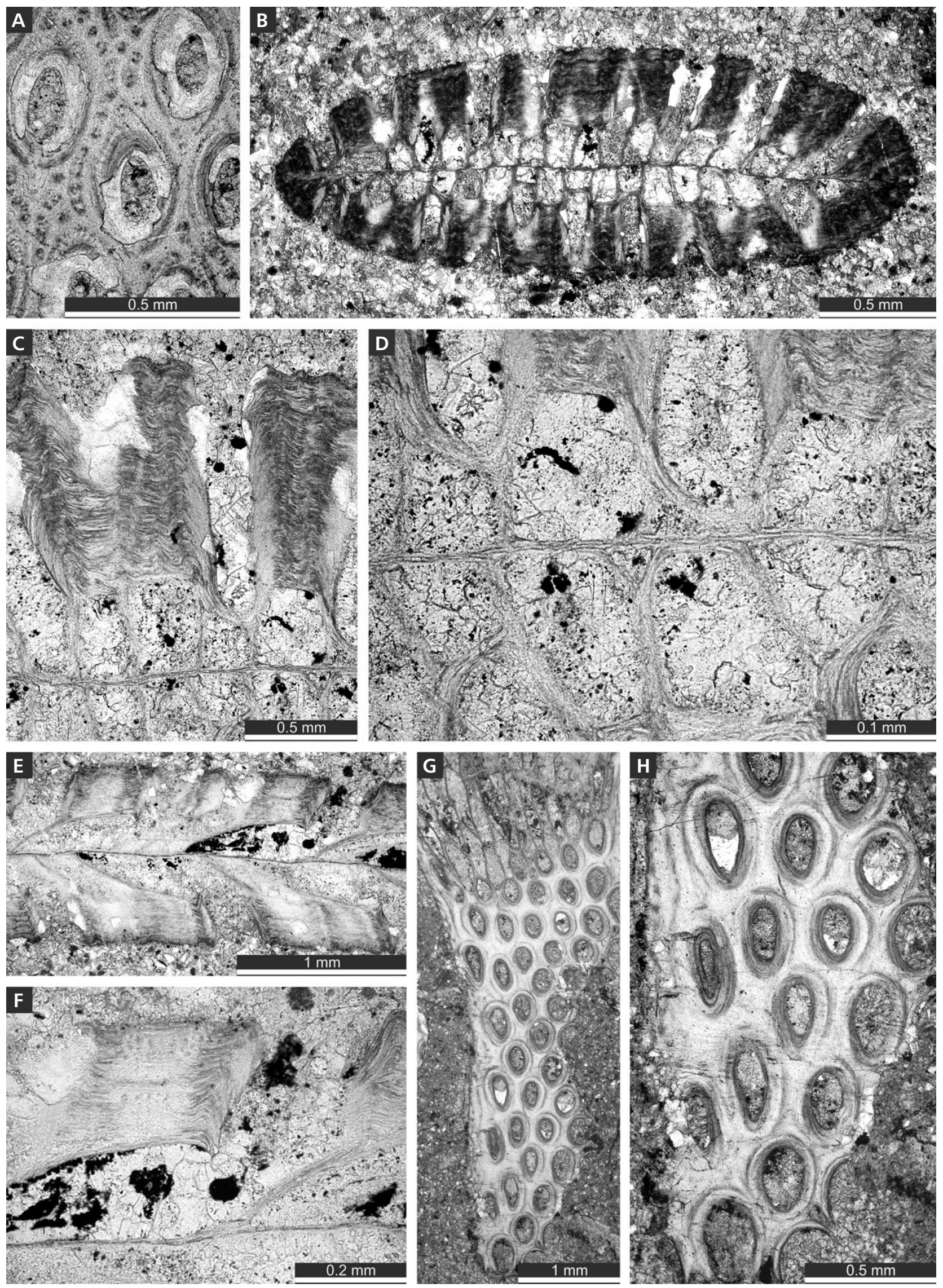
Table 8. Measurements of Oanduellina leuchtenbergi Pushkin, 1977. Abbreviations as in Table 1 .

\begin{tabular}{|c|c|c|c|c|c|c|}
\hline & $\mathrm{N}$ & $\mathrm{X}$ & SD & $\mathrm{CV}$ & MIN & MAX \\
\hline Branch width, mm & 5 & 2.49 & 0.274 & 11.03 & 2.13 & 2.75 \\
\hline Branch thickness, mm & 6 & 0.74 & 0.119 & 16.15 & 0.58 & 0.83 \\
\hline Aperture width, mm & 25 & 0.11 & 0.011 & 9.67 & 0.09 & 0.13 \\
\hline $\begin{array}{l}\text { Aperture spacing along } \\
\text { branch, } \mathrm{mm}\end{array}$ & 25 & 0.55 & 0.070 & 12.65 & 0.43 & 0.78 \\
\hline $\begin{array}{l}\text { Aperture spacing diagonally, } \\
\mathrm{mm}\end{array}$ & 25 & 0.27 & 0.030 & 11.24 & 0.22 & 0.34 \\
\hline Vesicle width, mm & 25 & 0.06 & 0.015 & 26.06 & 0.04 & 0.10 \\
\hline Vesicle height, $\mathrm{mm}$ & 10 & 0.059 & 0.012 & 20.82 & 0.038 & 0.075 \\
\hline
\end{tabular}

hemisepta and maculae as well as in less regular arrangement of autozooecial apertures.

Occurrence. - Upper Ordovician (Sandbian-Katian); Estonia, Lithuania, NW Russia. Middle Ordovician; Arctic Russia. Upper Ordovician (Hirnantian); Mongolia, India. Lower Silurian (Llandovery); Estonia.

\section{Oanduellina leuchtenbergi Pushkin, 1977}

Figures $11 \mathrm{G}-\mathrm{H}, 12 \mathrm{~A}-\mathrm{H}$, Table 8

1911 Pachydictya flabellum Bassler, p. 140, pl. 8, figs 1, 2, text-figs 63, 64.

1977 Oanduellina leuchtenbergi Pushkin, p. 69, pl. 7, figs 1,2 , text-fig. 1 .

1993 Oanduellina leuchtenbergi Pushkin, 1977. - Gorjunova \& Lavrentjeva, p. 61, pl. 9, figs 1, 2.

Material. - PMO 221.314, 221.317, 221.324-221.326, 221.331, 221.338, 221.340, 221.341-221.343, 221.345, 221.347-221.350, 221.351, 221.352, 221.355, 221.357, 221.359, 221.361-221.362, 221.365-221.366, 221.368.

Description. - Bifoliate branched colonies, locally anastomosed, 2.13-2.75 mm wide, 0.58-0.83 mm thick. Mesotheca straight, $0.008-0.018 \mathrm{~mm}$ thick; median rods lacking. Autozooecia short with flattened proximal parts, rectangular with rounded roofs in transverse section, rectangular at their bases, oval to slightly rhombic in deep tangential section. Autozooecial apertures oval, arranged in 14-18 irregular rows. Hemisepta absent. Autozooecial diaphragms absent. Abundant polygonal vesicles between apertures, moderate in size, commonly covered by extrazooidal material, having flat rounded roofs. Extrazooidal material containing paurostyles, $0.02-0.03 \mathrm{~mm}$ in diameter. Autozooecial walls coarsely laminated. Maculae absent.

Comparison. - Oanduellina leuchtenbergi Pushkin, 1977 differs from $O$. bella Lavrentjeva (in Gorjunova \& Lavrentjeva, 1993) from the Upper Ordovician of Estonia in having branched colony shape instead of reticulate one and in smaller autozooecial apertures (aperture width 0.09 to $0.13 \mathrm{~mm}$ vs. $0.15-0.20 \mathrm{~mm}$ in O. bella). Oanduellina leuchtenbergi differs from O. maculata Pushkin, 1977 in having smaller apertures (aperture width 0.09 to $0.13 \mathrm{~mm}$ vs. $0.10-0.16 \mathrm{~mm}$ in $O$. maculata) and in absence of maculae.

Occurrence. - Upper Ordovician (Sandbian, Nabala Stage); Latvia. Upper Ordovician (Sandbian, Oandu Stage); Lithuania. Upper Ordovician (Sandbian, Rakvere Stage); Estonia. Furuberget Formation, Upper Ordovician (Sandbian); Norway.

Family Ptilodictyidae Zittel, 1880

\section{Genus Phaenopora Hall, 1851} [= Fimbriapora Astrova, 1965]

Type species. - Phaenopora explanata Hall, 1852. Silurian; Canada.

Diagnosis. - Bifoliate colonies, straight or branched. Mesotheca straight, thin. Autozooecia almost straight. Diaphragms absent. Single superior or both superior and inferior hemisepta developed. Autozooecial apertures oval, rounded-rectangular. Ridges between autozooecial rows usually developed, sometimes absent at lateral parts of branches. Usually two metazooecia between apertures. Monticules consisting of metazooecia may present.

Comparison. - The genus Phaenopora Hall, 1851 differs from the genus Phaenoporella Nekhoroshev, 1956 by the branched colony shape instead of reticulated one, from the genus Eichwaldictya Lavrentjeva, 1990 - by absence of diaphragms and constant development of metazooecia.

Occurrence. - Middle Ordovician-Middle Silurian; North America, Siberia, Mongolia, Europe.

Figure 12. A-H - Oanduellina leuchtenbergi Pushkin, 1977. • A - tangential section, short detail, PMO 221.355. • B - branch transverse section, short detail, PMO 221.345. $\bullet \mathrm{C}$, D - transverse section showing autozooecial chambers, vesicles and mesotheca, PMO 221.346. $\bullet$ E, F - longitudinal section, short details, PMO 221.341. • G, H - tangential section showing vesicles and paurostyles, PMO 221.357. • I - Phaenopora similis Nekhoroshev, 1961, branch transverse section, short detail, PMO 221.345. 

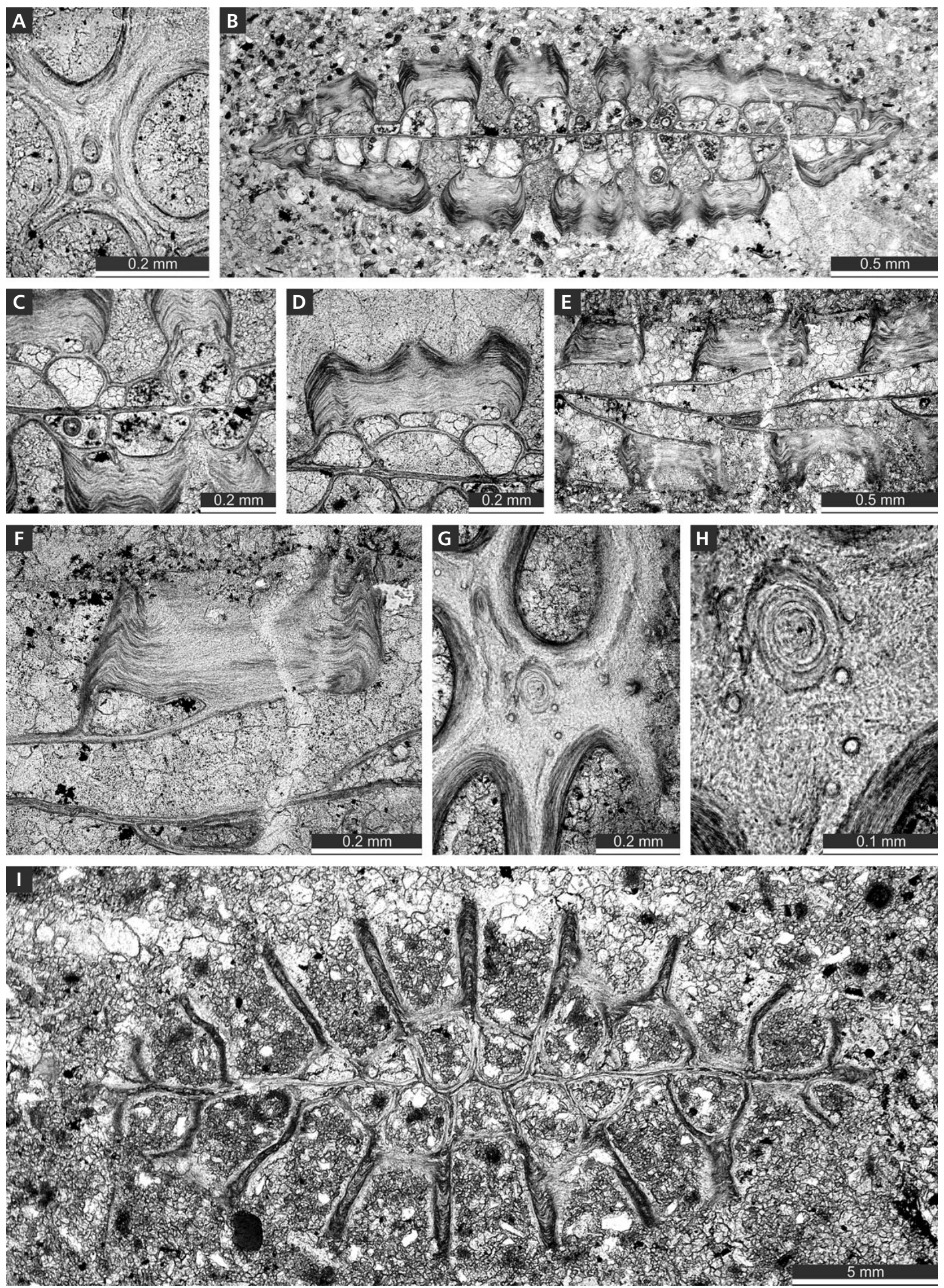
Table 9. Measurements of Phaenopora similis Nekhoroshev, 1961. Abbreviations as in Table 1.

\begin{tabular}{lrccccc}
\hline & $\mathrm{N}$ & $\mathrm{X}$ & $\mathrm{SD}$ & $\mathrm{CV}$ & $\mathrm{MIN}$ & $\mathrm{MAX}$ \\
\hline Branch width, mm & 5 & 1.99 & 0.595 & 29.88 & 1.10 & 2.70 \\
Branch thickness, mm & 3 & 0.99 & 0.079 & 8.02 & 0.90 & 1.05 \\
$\begin{array}{l}\text { Aperture width, mm } \\
\begin{array}{l}\text { Aperture spacing along branch, } \\
\text { mm }\end{array}\end{array}$ & 30 & 0.11 & 0.007 & 6.04 & 0.10 & 0.12 \\
$\begin{array}{l}\text { Aperture spacing diagonally, } \\
\text { mm }\end{array}$ & 30 & 0.28 & 0.033 & 11.98 & 0.20 & 0.34 \\
Metazooecia width, mm & 15 & 0.02 & 0.008 & 32.83 & 0.02 & 0.05 \\
\hline
\end{tabular}

Table 10. Measurements of Ptilodictya capillaris Lavrentjeva (in Lavrentjeva \& Gorjunova, 1993). Abbreviations as in Table 1.

\begin{tabular}{lcccccc}
\hline & $\mathrm{N}$ & $\mathrm{X}$ & $\mathrm{SD}$ & $\mathrm{CV}$ & $\mathrm{MIN}$ & $\mathrm{MAX}$ \\
\hline Aperture width, mm & 20 & 0.09 & 0.016 & 19.15 & 0.07 & 0.12 \\
$\begin{array}{l}\text { Aperture spacing along branch, } \\
\mathrm{mm}\end{array}$ & 20 & 0.31 & 0.014 & 4.44 & 0.28 & 0.34 \\
$\begin{array}{l}\text { Aperture spacing diagonally, } \\
\mathrm{mm}\end{array}$ & 20 & 0.24 & 0.022 & 9.16 & 0.18 & 0.26 \\
\hline
\end{tabular}

Phaenopora similis Nekhoroshev, 1961

Figures 12I, 13A-C, Table 9

1961 Phaenopora similis Nekhoroshev, pp. 72, 73, pl. 5, figs 4-6.

Material. - PMO 221.297, 221.298, 221.301, 221.305 to 221.306, 221.310, 221.331, 221.343, 221.345-221.346, 221.348, 221.352, 221.356-221.357.

Description. - Broad and flattened bifoliate branches, 1.1-2.7 mm wide, 0.90-1.05 mm thick. Mesotheca zigzag folded in transverse section, three-layered, 0.015 to $0.020 \mathrm{~mm}$ thick. Autozooecia short, rectangular in deep tangential section. Autozooecial apertures oval to rectangular with rounded corners, arranged in 7-13 rows. Hemisepta not observed; occasional diaphragms occurring. Metazooecia small, shallow, having triangular apertures, arranged regularly in pairs between apertures. Autozooecial wall moderately thin, finely laminated.

Comparison. - Phaenopora similis Nekhoroshev, 1961 is similar to P. plebeia Nekhoroshev, 1961 from the Upper Ordovician-Lower Silurian of Siberia, but differs in having larger apertures (average aperture width $0.11 \mathrm{~mm}$ vs. $0.07 \mathrm{~mm}$ in P. plebeia). Phaenopora similis is also similar to P. oepiki Toots, 1952 from the Upper Ordovician of Estonia, but differ from it in having smaller metazooecia and smaller distances between apertures (average distance between apertures $0.28 \mathrm{~mm}$ vs. $0.33 \mathrm{~mm}$ in $P$. oepiki).

Occurrence. - Middle-Upper Ordovician; Siberia. Furuberget Formation, Upper Ordovician (Sandbian); Norway.

\section{Genus Ptilodictya Lonsdale, 1839}

Type species. - Flustra lanceolata Goldfuss, 1829. Lower Silurian (Wenlock); Great Britain.

Diagnosis. - Colonies lancet or belt form, rarely dichotomous ramose. Mesotheca straight, locally zigzag, sometimes thickened in exozone. Autozooecia straight, tubular, long; sub-rectangular to sub-hexagonal in endozone; commonly sub-rectangular in exozone, rarely oval. Apertures arranged in longitudinal rows, separated by straight ridges. Diaphragms absent. Hemisepta present: superior and sometimes inferior. Monticules irregularly distributed, flat to slightly raised.

Comparison. - Ptilodictya Lonsdale, 1839 differs from Cladodictya Lavrentjeva in Gorjunova \& Lavrentjeva, 1993 in having longer autozooecia and presence of ridges.

Occurrence. - Middle Ordovician to Lower Devonian; North America, Europe and Siberia.

\section{Ptilodictya capillaris Lavrentjeva (in Gorjunova \& Lavrentjeva, 1993)}

Figure 13D-G, Table 10

1993 Ptilodictya capillaris Lavrentjeva (in Gorjunova \& Lavrentjeva, 1993), pp. 66, 67, pl. 10, figs 5, 6.

Material. - Single colony PMO 221.356.

Description. - Bifoliate branched colony, $1.53 \mathrm{~mm}$ wide. Mesotheca zigzag folded, three-layered; median rods lacking. Autozooecia moderately long, rectangular in deep tangential section. Autozooecial apertures oval to rectangular with rounded corners, arranged in 7-8 rows.

Figure 13. A-C - Phaenopora similis Nekhoroshev, 1961, tangential section showing autozooecial apertures and metazooecia, PMO 221.357. - D-G - Ptilodictya capillaris Lavrentjeva (in Gorjunova \& Lavrentjeva, 1993), PMO 221.356. D - oblique section of the colony. short detail. • E, F - tangential section showing autozooecial apertures and spherules in autozooecial walls. $\bullet \mathrm{G}$ - longitudinal section showing autozooecial chambers with diaphragms. 


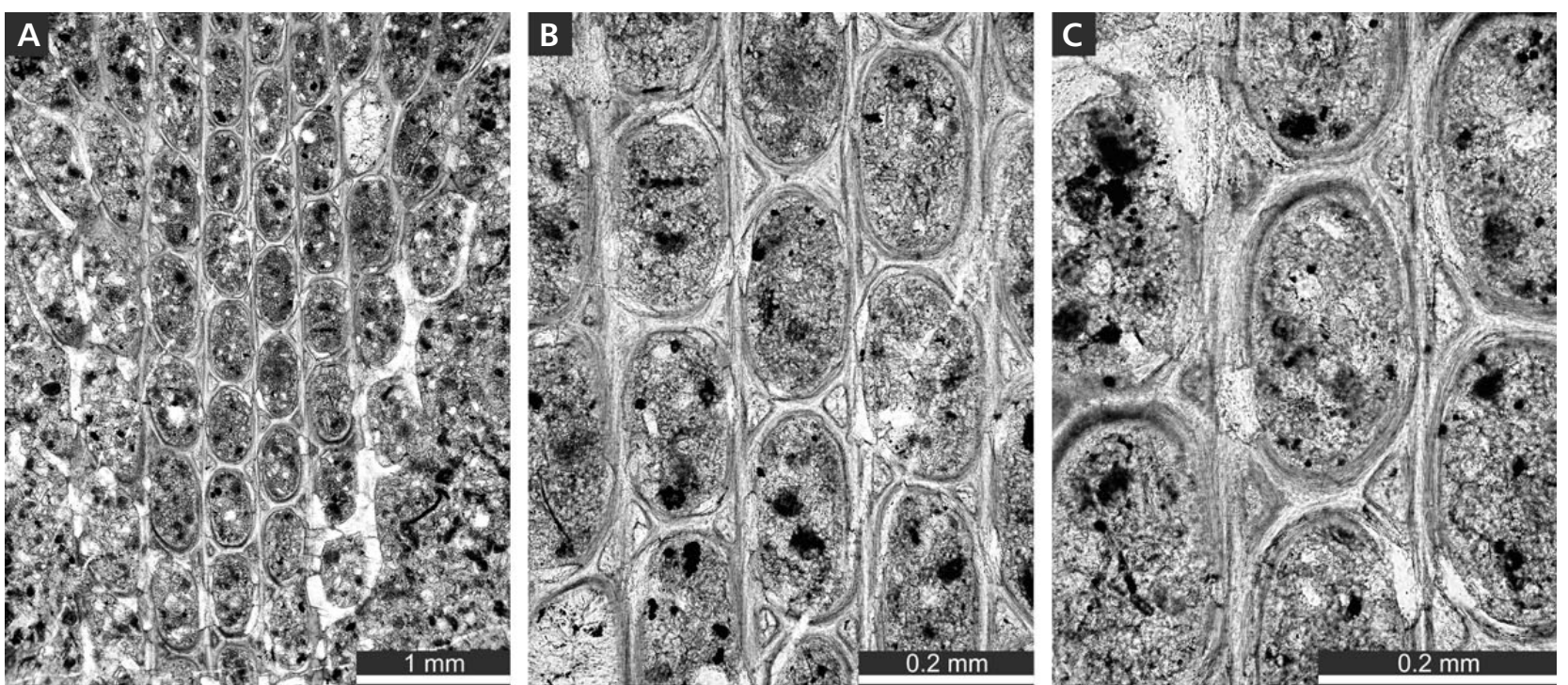

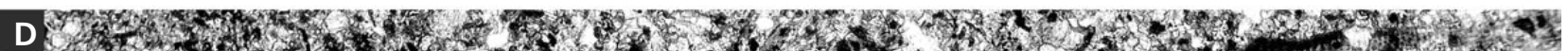

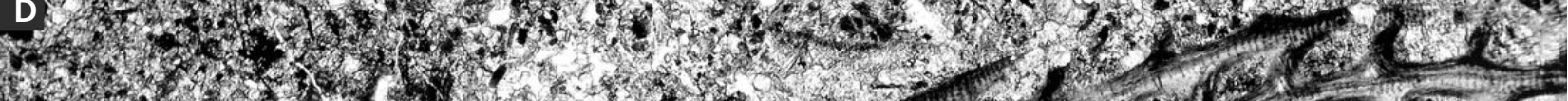

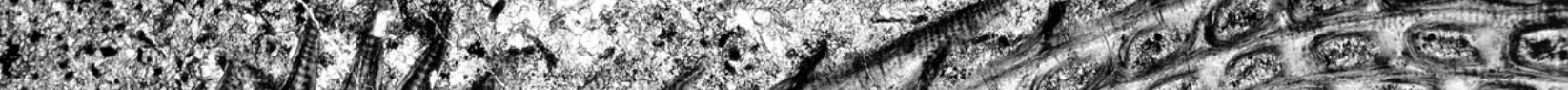

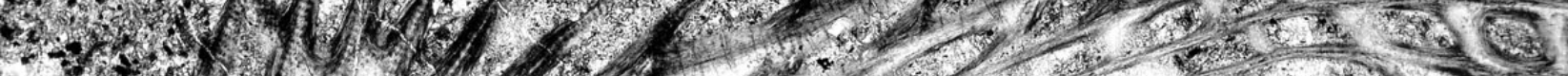

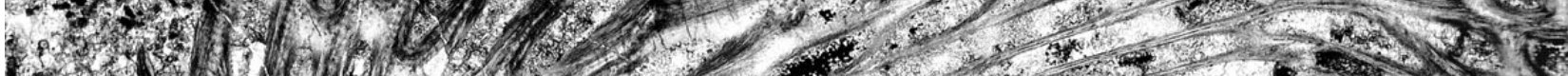

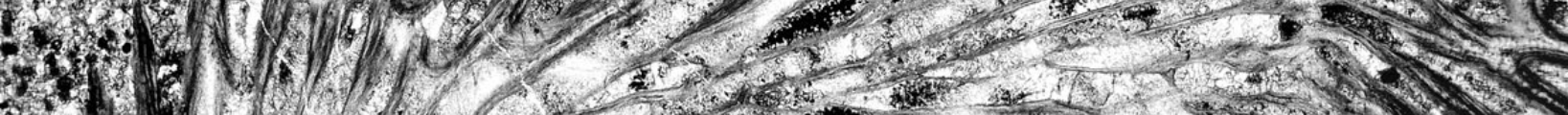

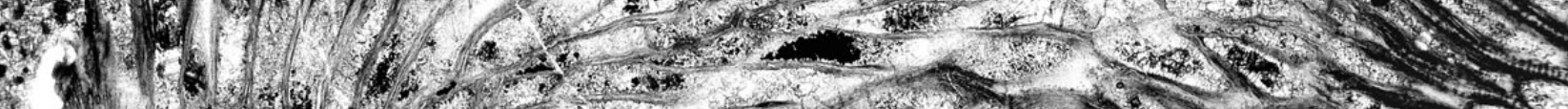

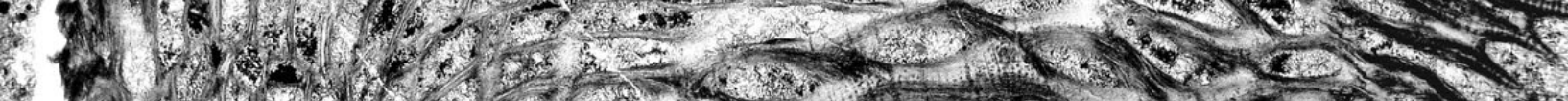

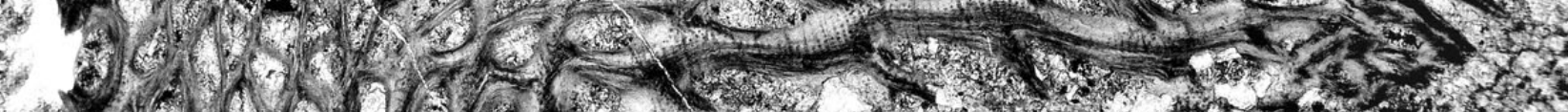

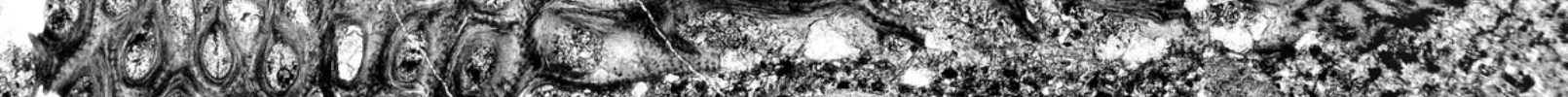

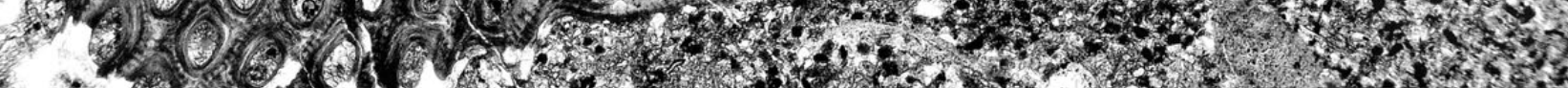

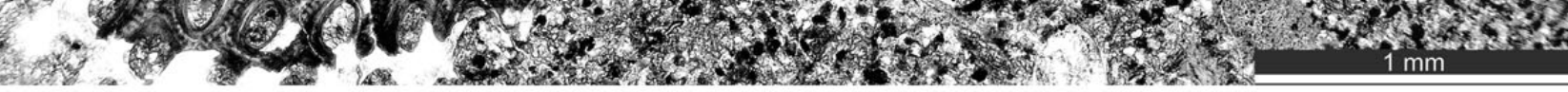
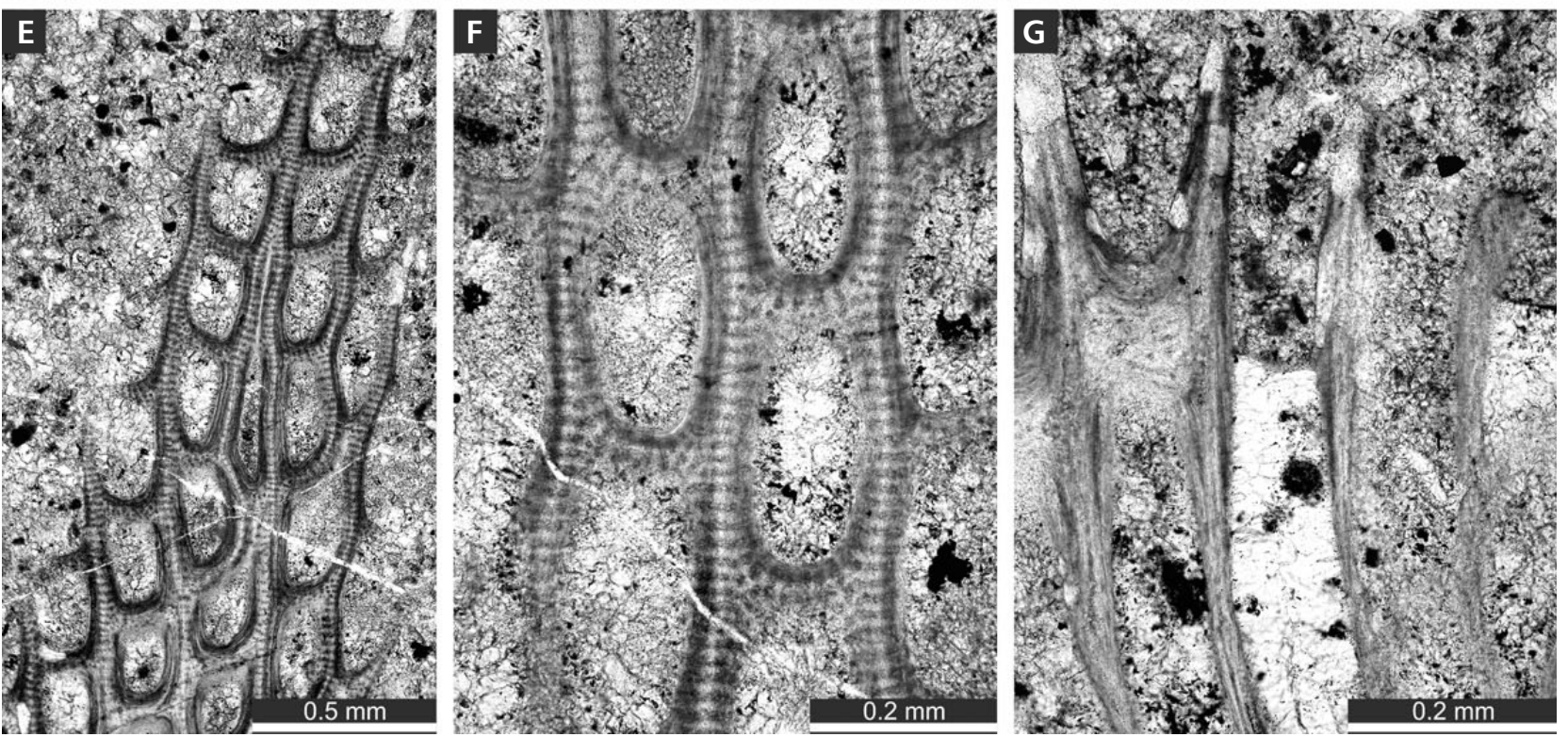
Superior hemisepta weakly developed; inferior hemisepta not observed. Occasional thin diaphragms occurring. Heterozooecia and styles absent. Autozooecial walls in endozone laminated with dark dividing layer, 0.015-0.025 mm thick; in exozone coarsely laminated, containing numerous spherules in autozooecia walls, regularly arranged in transverse bands. Spherules 0.005 to $0.010 \mathrm{~mm}$ in diameter.

Comparison. - Ptilodictya capillaris Lavrentjeva (in Gorjunova \& Lavrentjeva, 1993) is similar to P. exilis Lavrentjeva (in Gorjunova \& Lavrentjeva, 1993), but differs from it in having wider branches ( $1.53 \mathrm{~mm}$ vs. $0.7-1.0 \mathrm{~mm}$ in $P$. exilis).

Occurrence. - Middle Ordovician (Sandbian, Keila-Nabala Stages); Lithuania, Latvia. Furuberget Formation, Upper Ordovician (Sandbian); Norway.

\section{Conclusions}

The bryozoans described herein comprise a fauna of 10 previously known species. The species belong to nine genera previously known from other Baltoscandian as well as North American occurrences of Sandbian-Katian age. The Furuberget Formation faunas are completely different from those in the overlying unit (the Mjøsa Formation) and only one genus is shared (Eridotrypa) (Ernst \& Nakrem, in press). The biogeography of Late Ordovician bryozoans has been discussed in Ross (1985), Tuckey (1990), Anstey et al. (2003), Jiménez-Sánchez (2009), Kácha \& Šarič (2009), Jiménez-Sánchez \& Villas (2010), Taylor \& Sendino (2010) and briefly in Ernst \& Nakrem (in press). On species level the Furuberget Formation bryozoan fauna resembles very much time equivalent units in the Baltic province, as well as North American (Laurentian) faunas. Slightly younger bryozoans from the Mjøsa Formation are rather different from Laurentian faunas indicating that there were more marine communication and less endemism in the Sandbian as compared with the Katian. All species are new additions for the Norwegian Ordovician to the bryozoan database used by e.g. Anstey et al. (2003) and Jiménez-Sánchez \& Villas (2010).

\section{Acknowledgements}

We are grateful to Magne Høyberget and Bjørn Funke for their help on our field trip to the studied locality. We also thank Patrick Wyse Jackson, Dublin, and Françoise Bigey, Paris, for constructive and helpful reviews. The Deutsche Akademische Austauschdienst (DAAD) supported Andrej Ernst's study visit to the Natural History Museum, University of Oslo, with a one-year fellowship 2001-2002 (grant D/02/00949).

\section{References}

Anstey, R.L. \& Perry, T.G. 1970. Biometric procedures in taxonomic studies of Paleozoic bryozoans. Journal of Paleontology 44, 383-398.

Anstey, R.L., Pachut, J.F. \& Tuckey, E. 2003. Patterns of bryozoan endemism through the Ordovician-Silurian transition. Paleobiology 29, 305-328.

DOI 10.1666/0094-8373(2003)029<0305:POBETT>2.0.CO;2

Astrova, G.G. 1965. Morphology, history of development and sytematics of the Ordovician and Silurian Bryozoa. Trudy Paleontologicheskogo Instituta Akademii Nauk SSSR 106, 1-432. [in Russian]

Astrova, G.G. \& Morozova, I.P. 1956. About systematics of the order Cryptostomata. Doklady Akademii Nauk SSSR 110(4), 661-664. [in Russian]

BAssLer, R.S. 1911. The Early Paleozoic Bryozoa of the Baltic Provinces. Bulletin of the United States National Museum 77, 1-382.

Bassler, R.S. 1953. Bryozoa, Vol. Part G, 1-253. In Moore, R.C. (ed.) Treatise on Invertebrate Paleontology. Geological Society of America and University of Kansas Press, Lawrence, Kansas.

Bergström, S.M., Schmitz, B., Young, S.A. \& Bruton, D.L. 2011. Lower Katian (Upper Ordovician) $\delta^{13} \mathrm{C}$ chemostratigraphy, global correlation and sea-level changes in Baltoscandia. GFF 133, 1-17.

Borg, F. 1926. Studies on Recent cyclostomatous Bryozoa. Zoologiska Bidrag fran Uppsala 10, 181-507.

Brood, K. 1973. Palaeozoic Cyclostomata (a preliminary report), 247-256. In LARwood, G.P. (ed.) Living and fossil Bryozoa. Academic Press, London.

Busk, G. 1852. An account of the Polyzoa, and sertularian Zoophytes, collected in the Voyage of the Rattlesnake on the Coasts of Australia and the Loisiade Archipelago, 343-402. In MacGillivray, J. (ed.) Narrative of the Voyage of H.M.S. Rattlesnake, ... during the years 1846-1850, Volume 1. T.W. Boone, London.

Conti, S. 1990. Upper Ordovician Bryozoa from Sardinia. Palaeontographica italica 77, 85-165.

Cumings, E.R. 1908. Stratigraphy and paleontology of the Cincinnati Series of Indiana. Bulletin of Indiana Geological Survey 32, 605-1188.

Dyвowski, W. 1877. Die Chaetetiden der ostbaltischen Silur-Formation. Russische Kaiserliche Mineralogische Gesellschaft zu St. Petersburg, Verhandlungen, Series 2(14), 1-134.

DzIK, J. 1981. Evolutionary relationships of the Early Palaeozoic "Cyclostomatous" Bryozoa. Palaeontology 24, 827-861.

Ehrenberg, C.G. 1831. Symbolae Physicae, seu Icones et descptiones Corporum Naturalium novorum aut minus cognitorum, quae ex itineribus per Libyam, Aegiptum, Nubiam, Dongalaam, Syriam, Arabiam et Habessiniam, studia annis 1820-25, redirent. Pars Zoologica, 4, Animalia Evertebrata exclusis Insectis. 10 pls. Berolini.

EICHWALD, E. 1855. Beitrag zur geographischen Verbreitung der fossilen Tiere Russlands. Alte Periode. Bulletin de la Société des Naturalistes de Moscou 28, 433-466.

Eichwald, E. 1860. Lethaea Rossica, ou Paléontologie de la Russie. I. Ancienne Periode. 682 pp. 4 to Atlas of 59 pls. 
[Bryozoa, pp. 355-419, 434-435, 450-452, 475-494, pls xxlii-xxviii, xxx, xxxiii.] Schweizerbart, Stuttgart.

ERnst, A. \& Key, M. 2007. Upper Ordovician Bryozoa from the Montagne de Noire, southern France. Journal of Systematic Palaeontology 5(4), 359-428. DOI 10.1017/S1477201907002155

ERnst, A. \& NAKREM, H.A. (in press). Bryozoans from the Ordovician Mjøsa Formation, Oslo Region. Norwegian Journal of Geology.

Goldfuss, G.A. 1829. Petrefacta Germaniae, Abbildung und Beschreibung der Petrefacten Deutschlands und angrenzender Länder. Band 1, Lieferung 2, 77-164. Arnz and Co., Düsseldorf.

GorjunOva, R.V. \& LavrentueVA, V.D. 1993. Morphology and systematics of the cryptostome bryozoans. Trudy Paleontologicheskogo Instituta Rossiiskoi Akademii Nauk 257, 1-152. [in Russian]

HaGEMAN, S.J. 1993. Effects of nonnormality on studies of the morphological variation of a rhabdomesine bryozoan, Streblotrypa (Streblascopora) prisca (Gabb \& Horn). The University of Kansas Paleontological Contributions 4, 1-13.

Hall, J. 1847. Organic remains of the lower division of the New-York system (equivalent of the Silurian Rocks of Europe). Natural History of New York, Part 6, Palaeontology of New York 1, 338 pp.

HaLl, J. 1851. New genera of fossil corals. American Journal of Sciences and Art 2, 398-401.

HaLl, J. 1852. Organic remains of the lower middle division of the New York system. Natural History of New York. Part 6. Palaeontology of New York 2, 40-52, 144-173.

JAMES, U.P. 1878. Descriptions of newly discovered species of fossils from the Lower Silurian Formation - Cincinnati Group. The Paleontologist 1, 1-8.

JiMÉNEZ-SÁNCHEZ, A. 2009. The upper Katian (Ordovician) bryozoans from the Eastern Iberian Chain (NE Spain). Bulletin of Geosciences 84(4), 687-738. DOI 10.3140/bull.geosci.1156

JiMÉNEZ-SÁnChEZ, A. \& Villas, E. 2010. The bryozoan dispersion into the Mediterranean margin of Gondwana during the pre-glacial Late Ordovician. Palaeogeography, Palaeoclimatology, Palaeoecology 294, 220-231. DOI 10.1016/j.palaeo.2009.11.027

KÁCHA, P. \& ŠARIČ, R. 2009. Host preferences in Late Ordovician (Sandbian) epibenthic bryozoans: example from the Zahořany Formation of Prague Basin. Bulletin of Geosciences 84(1), 169-178. DOI 10.3140/bull.geosci.1048

KARKLINS, O.L. 1983. Systematic descriptions for the Suborder Ptilodictyina, 489-529. In RoBIson, R.A. (ed.) Treatise on Invertebrate Paleontology, Part G (1). Bryozoa (revised). Geological Society of America and University of Kansas Press, Boulder.

KaRKLINS, O.L. 1984. Trepostome and cystoporate bryozoans from the Lexington Limestone and the Clays Ferry Formation (Middle and Upper Ordovician) of Kentucky, I1-I102. In POJETA, J. JR. (ed.) Contributions to the Ordovician paleontology of Kentucky and nearby states. United States Geological Survey, Professional Paper 1066-I.

Lavrentueva, V.D. 1990. A new genus of cryptostomate bryozoans. Paleontological Journal 24, 130-133.

Lonsdale, W. 1839. Corals, 675-694. In Murchison, R.I. (ed.)
The Silurian System. Part 2. Organic remains. John Murray, London.

MäNNIL, R.M. 1958. New bryozoans of the order Cryptostomata from the Ordovician of Estonia. Eesti NSV Teaduste Akadeemia Toimetised, Tehniliste ja füüsikalis-matemaatiliste teaduste seeria 7, 330-347. [in Russian].

Miller, S.A. 1889. North American Geology and Paleontology for the use of amateurs, students, and scientists. 664 pp. Western Methodist Book concern, Cinncinnati.

Miller, S.A. \& Dyer, C.B. 1878. Contributions to paleontology. Cincinnati. Journal of the Cincinnati Society of Natural History 2, 1-11.

Milne-Edwards, H. \& Haime, J. 1851. Monographie des polypiers fossiles des terrains paléozoïques, précédé d'un tableau général de la classification des Polypes. Archives du Muséum d'Histoire Naturelle 5, 1-504.

Modzalevskaya, E.A. 1953. Trepostomata of the Ordovician of East Baltic and their stratigraphic significance. Trudy Vsesojuznogo Nauchnoissledovatelskogo Geologo-Razvedochnogo Instituta (VNIGRI) 78, 91-167. [in Russian].

Nekhoroshev, V.P. 1956. Class Bryozoa. In Materialy po paleontologii, novye semeistva i rody. Materialy VSEGEI, New Series 7, 42-49. [in Russian]

NeKHoroshev, V.P. 1961. Ordovician and Silurian bryozoans of Siberian Plate. Trudy VSEGEI, New Series 41, 1-246. [in Russian]

NichOLSON, H.A. 1874. Descriptions of species of Chaetetes from Lower Silurian rocks of North America. Quarterly Journal of the Geological Society, London 30, 499-515. DOI 10.1144/GSL.JGS.1874.030.01-04.52

Nicholson, H.A. 1879. On the structure and affinities of the "Tabulate Corals" of the Paleozoic period, with critical descriptions of illustrative species. $342 \mathrm{pp}$. William Blackwood and Sons, Edinburgh.

Nicholson, H.A. 1881. On the structure and affinities of the genus Monticulipora and its subgenera with critical descriptions of illustrative species. $240 \mathrm{pp}$. William Blackwood and Sons, Edinburgh.

Nickles, J.M. \& BASSLER, R.S. 1900. A synopsis of American fossil Bryozoa, including bibliography and synonymy. U.S. Geological Survey Bulletin 173, 1-663.

OrbignY, A.D. D' 1850. Prodrome de paléontologie stratigraphique universelle des animaux mollusques rayonnés, faisant suite ou cours élémentaire de paléontologie et géologie stratigraphique. Volume 1. 394 pp. Victor Masson, Paris.

Owen, A., Bruton, D.L., Bockelie, J.F. \& Bockelie, T.G. 1990. The Ordovician successions of the Oslo Region, Norway. Norges Geologiske Undersøkelse Special Publication 4, 1-54.

PhilLIPS, J.R.P. 1960. Restudy of types of seven Ordovician bifoliate Bryozoa. Palaeontology 3, 1-25.

Pushkin, V.I. 1977. New genus of the Ordovician Bryozoan. Paleontologicheskiy Zhurnal 4, 67-72. [in Russian]

Ross, J.R.P. 1969. Champlainian (Ordovician) Ectoprocta (Bryozoa), New York state, part II. Journal of Paleontology 43, 257-284.

Ross, J.R.P. 1985. Biogeography of Ordovician ectoproct (bryozoan) faunas, 265-272. In Nielsen, C. \& LARwood, G.P. (eds) Bryozoa: Ordovician to Recent. Olsen and Olsen, Fredensborg, Denmark. 
SingH, R.J. 1979. Trepostomatous bryozoan fauna from the Bellevue Limestone, Upper Ordovician in the tri-state area of Ohio, Indiana and Kentucky. Bulletins of American Paleontology $76,161-288$.

SpJELDNAes, N. 1984. Upper Ordovician bryozoans from Oj1 Myr, Gotland, Sweden. Bulletin of the Geological Institutions of the University of Uppsala, New Series 10, 1-66.

TAYLOR, P.D. \& SENDINO, C. 2010. Latitudinal distribution of bryozoan-rich sediments in the Ordovician. Bulletin of Geosciences 85(4), 565-572. DOI 10.3140/bull.geosci.1177

TAYLOR, P.D. \& WILSON, M.A. 1994. Corynotrypa from the Ordovician of North America: colony growth in a primitive stenolaemate bryozoan. Journal of Paleontology 68, 241-257.

Toots, H. 1952. Bryozoen des estnischen Kuckersits. Mitteilungen aus dem Geologischen Staatsinstitut in Hamburg 21, 113-137.

TuCKeY, M.E. 1990. Biogeography of Ordovician bryozoans. Palaeogeography, Palaeoclimatology, Palaeoecology 77, 91-126. DOI 10.1016/0031-0182(90)90128-T

UlRICH, E.O. 1878. Descriptions of some new species of fossils from the Cincinnati Group. The Journal of the Cincinnati Society of Natural History 1, 92-100.
Ulrich, E.O. 1882. American Palaeozoic Bryozoa. The Journal of the Cincinnati Society of Natural History 5, 121-175, 233-257.

UlRICH, E.O. 1886. Descriptions of new Silurian and Devonian fossils. Bryozoa. Contributions to American Palaeontology 1, 3-35.

Ulrich, E.O. 1890. Palaeozoic Bryozoa. Palaeontology of Illinois. Geological Survey of Illinois 8 Part II, Section VI, 283-688.

ULRICH, E.O. 1893. On Lower Silurian Bryozoa of Minnesota. The Geological and Natural History Survey of Minnesota, final report 3, 96-332.

UlRICH, E.O. \& BASSLER, R.S. 1904. A revision of the Palaeozoic Bryozoa. Part II. On genera and species of Trepostomata. Bulletin of the US Geological Survey 173, 15-55.

VinASSA DE REGNY, P. 1921. Sulla classificazione die trepostomidi. Societa Italiana di Scienze Naturali Atti 59, 212-231.

VINE, G.R. 1884. Fourth report of the Committee consisting of Dr. H.R. Sorby and Mr. G.R. Vine, appointed for the purpose of reporting on fossil Polyzoa. In Report of the Fifty-third meeting of the British Association for the Advancement of Science London (Southport, 1883), 161-209. John Murray, London.

ZitTel, K.A. 1880. Handbuch der Palaeontologie. Abteilung 5. Palaeozoologie 1.765 pp. Oldenbourg, München. 